\title{
THE RIGHT TO DEVELOPMENT AS A NORMATIVE FRAMEWORK FOR THE HUMAN RIGHTS OBLIGATIONS OF INTERNATIONAL FINANCIAL INSTITUTIONS
}

A Mini Thesis Submitted in Partial Fulfillment of the Requirements for the Degree

LLM (Human Rights and Democratisation in Africa)

Faculty of Law, University of Pretoria

BY

Mesenbet Assefa Tadeg

Student No. 2882513

Prepared under the supervision of

Prof. Jaap de Visser

Faculty of Law, University of Western Cape

South Africa

November 2008 


\section{Declaration}

I declare that, 'The right to development as a normative framework for the human rights obligations of International Financial Institutions' is my work, that it has not been submitted before for any degree or examination in any other university, and that all the sources I have used or quoted have been indicated and acknowledged as complete references.

Mesenbet Assefa Tadeg

Signed.

3 November 20 


\section{Table of contents}

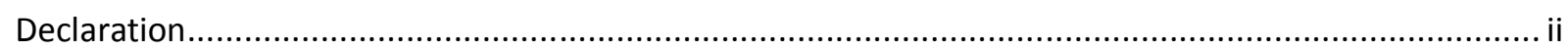

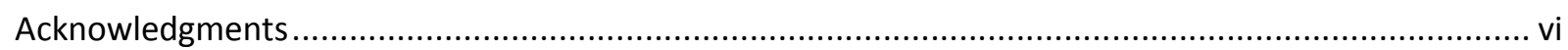

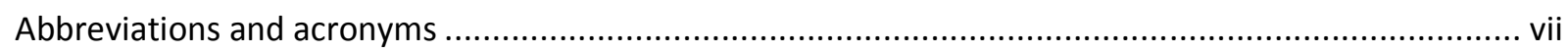

\section{Chapter one: Introduction}

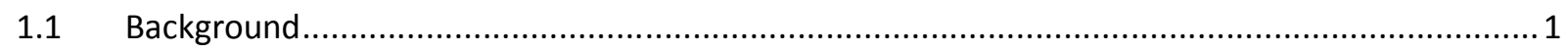

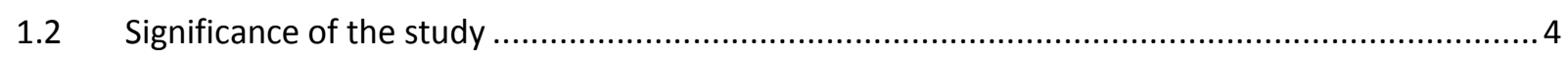

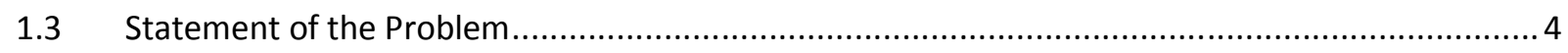

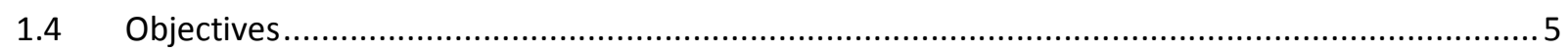

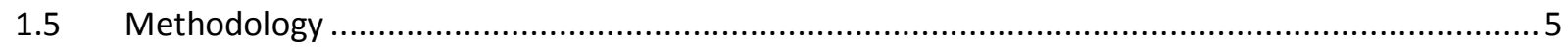

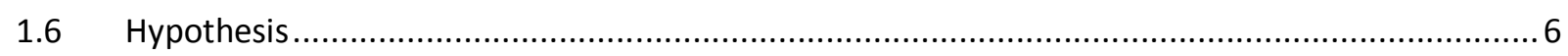

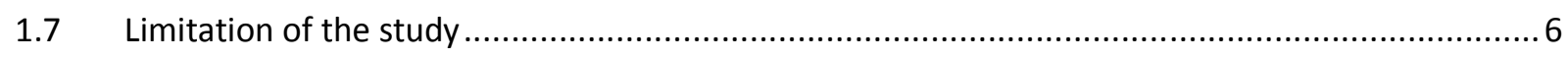

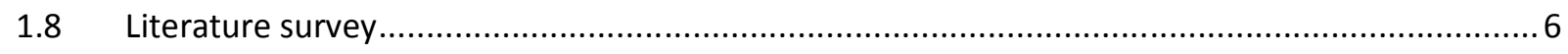

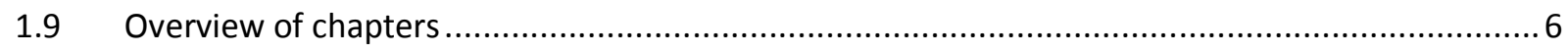

\section{Chapter two: The link between development and human rights}

2.1. Introduction .

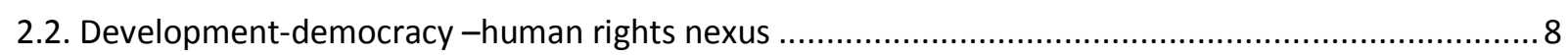

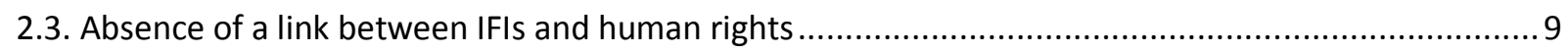

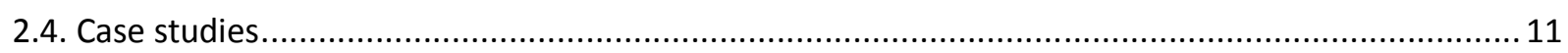

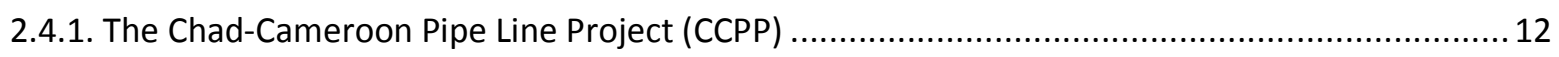

2.4.2. The Lagos Drainage and Sanitation Project-Nigeria ................................................................. 14

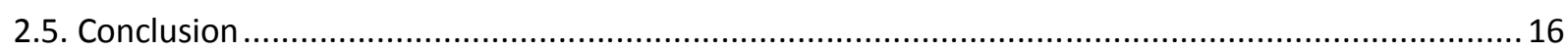




\section{Chapter three: IFIs and their policy implications on human rights}

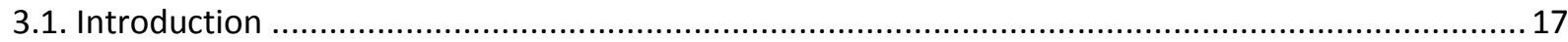

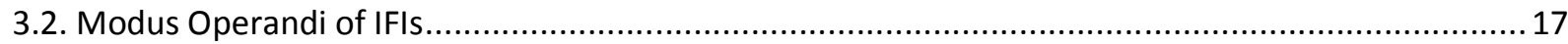

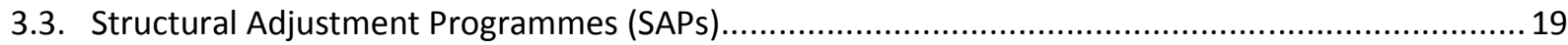

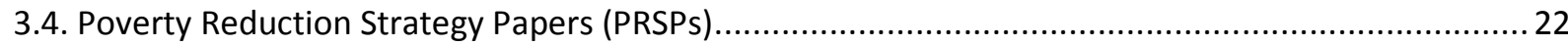

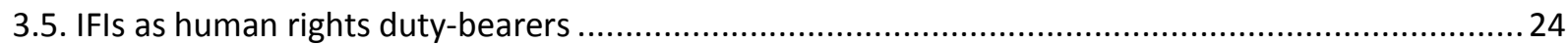

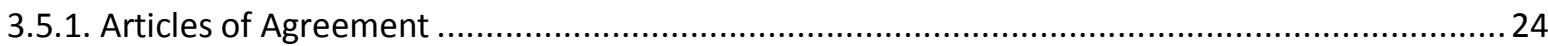

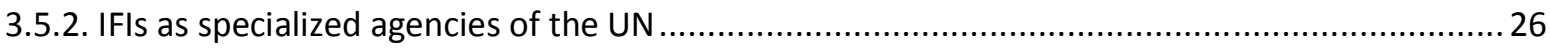

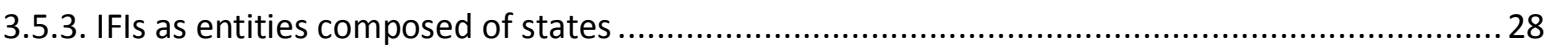

3.5.4. Human rights obligations of IFIs emanating from general rules of international law .................30

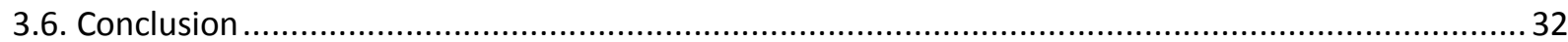

\section{Chapter four: The legal framework on the right to development -} implications for IFIs

4.1. Introduction 33

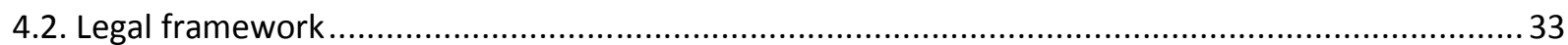

4.2.1. The Universal Declaration of Human Rights - a precursor to the right to development ...........34

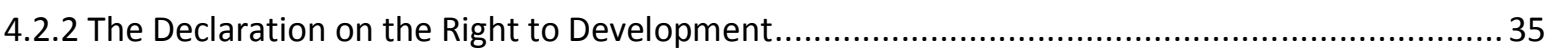

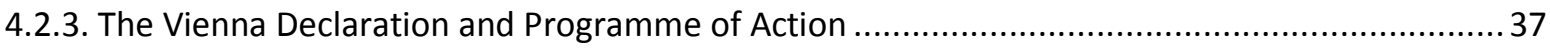

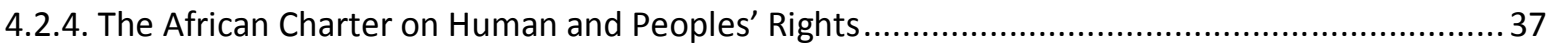

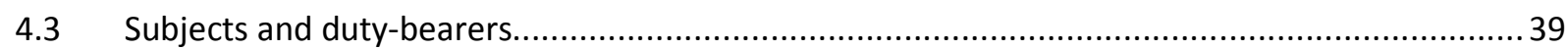

Concerns of justiciability and feasibility ................................................................. 41

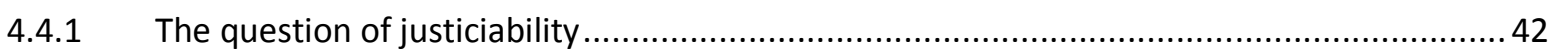

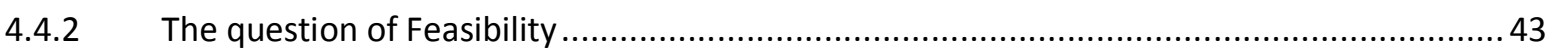

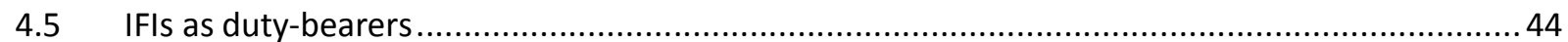

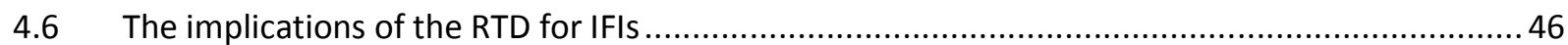

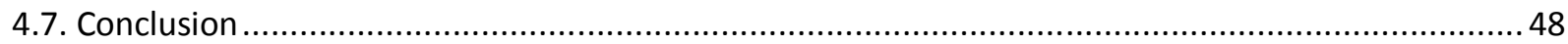


Chapter five: IFIs' human rights accountability emanating from the right to development

5.1. Introduction 49

5.2. Addressing problems of representation 49

5.3. Human rights conditionalities 51

5.4. The World Bank Inspection Panel.............................................................................. 52

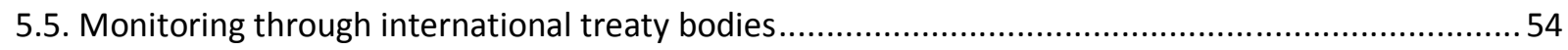

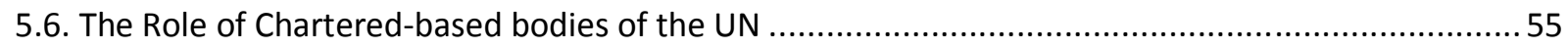

5.7. The Working Group on the Right to Development ......................................................56

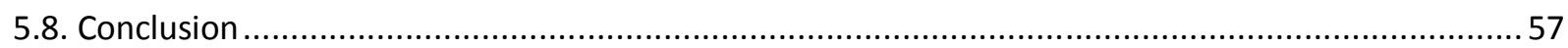

\section{Chapter six: Conclusion and recommendation}

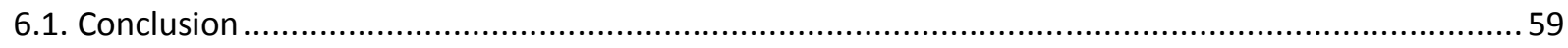

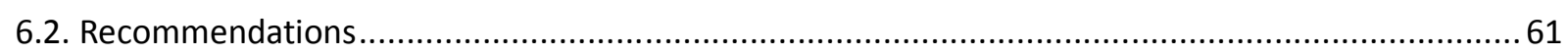

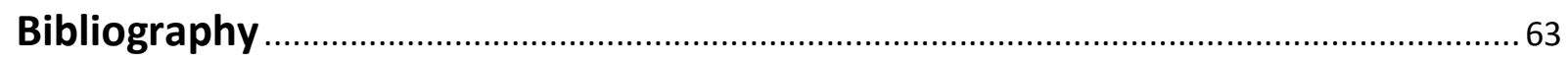

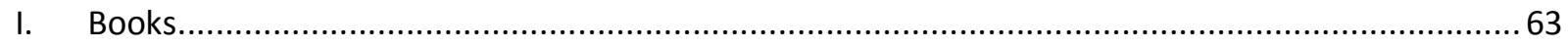

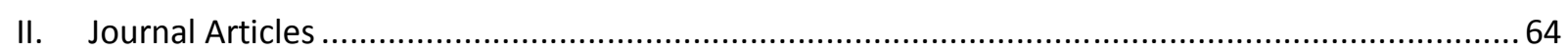

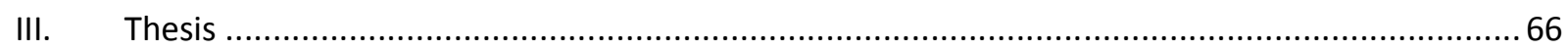

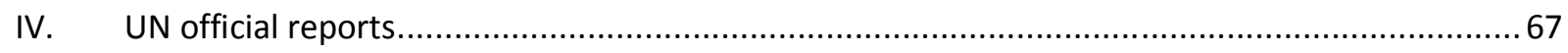

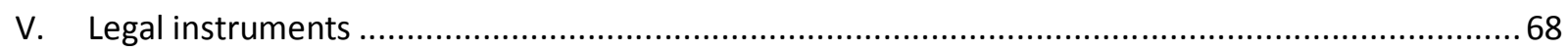

VI. General Comments, Decisions and concluding observations ........................................... 70

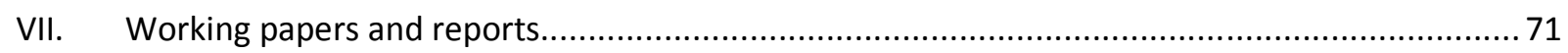

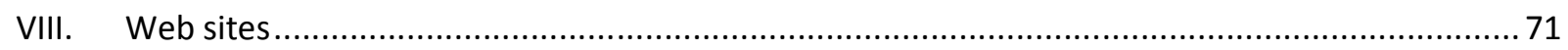

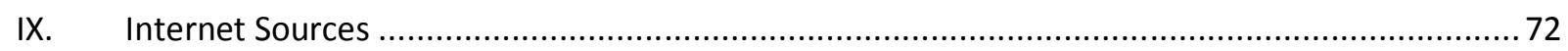

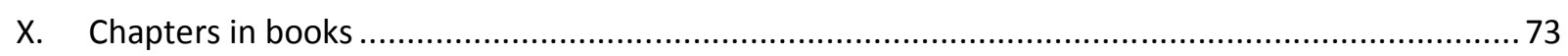

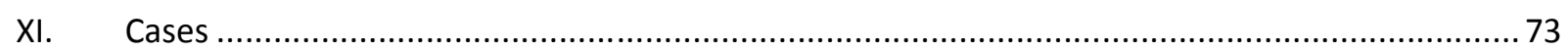




\section{Acknowledgments}

First and foremost, I would like to thank God for giving me the courage and strength to finish the research.

This research would not have also been possible without the support and help of several individuals.

I would like to express my most profound gratitude to my supervisor Prof. Jaap de Visser for his valuable and enriching comments throughout my work.

I am thankful to Prof. Michelo Hansungule for giving me the inspiration to pursue the thoughts that I truly believe in.

Thanks are owed to the staff of the Community Law Centre; in particular to Jill Claassen and Trudi Fortuin for their support in my research.

I would like to extend my deepest gratitude to students of the LLM class of 2008 for their moral support and for showing me the true spirit of UBUNTU. In particular, I am deeply indebted to Japheth Biegon, Hilary Ogbonna, Peace Ofei, Rhoda Igweta and Remember Miamingi for their valuable comments on my work and for making things easy throughout my studies. 


\section{Abbreviations and acronyms}

\begin{tabular}{ll} 
ACHPR & African Charter on Human and peoples' Rights \\
CESCR & Covenant on Economic, Social and Cultural Rights \\
Committee on ECSR & Committee on Economic, Social and Cultural Rights \\
CCPP & Chad-Cameroon Pipe Line Project \\
DRTD & Declaration on the Right to Development \\
ECOSOC & United Nations Economic and Social Council \\
GOC & Government of Chad \\
HIPC & Heavily Indebted Poor Countries \\
ICCPR & International Covenant on Civil and Political Rights \\
IMF & International Monetary Fund \\
IFIs & International Financial Institutions \\
NIEO & New International Economic Order \\
PRSPs & Poverty Reduction Strategy Papers \\
RTD & Right to Development \\
SAPs & United Nations Commission on Human Rights \\
UN & Utructural Adjustment Programmes \\
UNCTAD & United Nations \\
UNDP & United Nations Conference on Trade and Development \\
UNHCR & United Nations Development Programme \\
WGRT & Unoup on the Right to Developme \\
\hline
\end{tabular}




\section{Chapter One}

\section{Introduction}

\subsection{Background}

Human rights are the product of different stages of human struggle that took place throughout history. The advent of the right to development in the international arena is part of the result of the struggle of developing countries for a New International Economic Order (NIEO). ${ }^{1}$ The right to development belongs to the group of third generation rights which includes the right to healthy environment, and the right to peace. ${ }^{2}$ According to the proponents of third generation rights all actors in the social scene: the state, the individual, public and private firms and the entire international community need to have a concerted action for the realization of these rights. ${ }^{3}$ Supporters of third generation rights also stress the danger that globalization poses on existing human rights structures rendering individual states, acting alone unable to satisfy the obligations imposed by international human rights instruments. ${ }^{4}$

Since the idea of a 'Right to Development' (RTD) was coined by the Senegalese jurist Keba M'baye in 1972,5 the subject remains the focus of human rights and development literature. Legal scholars from the south articulated the notion and enumerated the possible subjects and objects of this right, while jurists from the north questioned whether such right existed at all. ${ }^{6}$

The collective struggle of developing countries for the establishment of international order that favours their special needs culminated in the adoption of the UN Declaration on the Establishment of a New International Economic Order GA Res. 3201(S-VI) U.N. GAOR 6 ${ }^{\text {th }}$ Special Sess. Agenda Item 6, $2229^{\text {th }}$ plen. Mgt. at U.N. Doc. A/RES/3201(S-VI) (1974).

$2 \quad$ O Sheehy 'The right to development and the proliferation of rights in international law' (2002) 5 Trinity Law Review 253.

$3 \quad$ Sheehy (n 2 above) 254.

$4 \quad$ Rich The right to development: a right of peoples? (1992) 312, cited (as above) 254.

$5 \quad \mathrm{~K}$ M'Baye Le droit au développement comme un droit de l'homme in Revue internationale des droits de l'homme vol. V 1972, cited in R L Barsh (1991) 'The right to development as a human right: results of the Global Consultation' 13 Human Rights Quarterly 322. 
In 1986 the United Nations (UN) General Assembly adopted the Declaration of the on the Right to Development (DRTD) 7 recognising the RTD as a fundamental human rights. The RTD has been reaffirmed by the Vienna Declaration and Programme of Action (Vienna Declaration) which was adopted by 171 countries participating in the World Conference on Human Rights in 1993, as a universal and inalienable right and an integral part of fundamental human rights. ${ }^{8}$ The African Charter on Human and Peoples' Rights (ACHPR)9 in Article 22 expressly incorporates this right; in fact, it is the only legally binding international document containing an express recognition of the RTD.

Under the UN, efforts are being made to implement the RTD through its charter-based bodies such as the Economic and Social Council (ECOSOC) and resolution-based working groups. In 1989, the Commission on Human Rights (UNCHR) established a Global Consultation on the Realisation of the Right to Development as a Human Right ${ }^{10}$ involving experts with relevant experience; representatives of the United Nations system, including its specialised agencies; regional intergovernmental organisations and Non Governmental Organisations (NGOs). Currently efforts are also being made for the implementation of the RTD under the Working Group on the Right to Development (WGRTD). ${ }^{11}$ Nevertheless, there are still formidable political, legal and socio-economic challenges that have impeded its realisation. One of the challenges for a meaningful realisation of the RTD has been the reluctance of the World Bank and IMF to integrate this notion in the development process.

The International Monetary Fund (IMF) and the World Bank ${ }^{12}$ were created in July 1944, in Bretton Woods, New Hampshire, in north-eastern United States when representatives of 45 governments met and agreed to set up a framework for international economic co-operation.

\footnotetext{
$6 \quad$ Barsh (n 5 above) 322.

7 Declaration on the Right to Development adopted by General Assembly Resolution 41/128 (4 Dec.1986).

8 Vienna Declaration and Programme of Action A/CONF.157/23 (12 Jul. 1993).

$9 \quad$ African Charter on Human and Peoples' Rights adopted (June 27 1981).

$10 \quad$ UN Commission on Human Rights Resolution 1989/45 (6 March 1989), 'The Realization of the Right to Development' Global Consultation on the Right to Development as a Human Right HR/PUB/91/2 United Nations, New York, (1991).

11 Open-Ended Working Group on the Right to Development E/CN/4.RES/1998/72.

12 Unless otherwise expressly stated, the term World Bank in this paper refers to the Word Bank group collectively. However it is important to note that the World Bank Group consists of four multi-lateral financial institutions: the International Bank of Reconstruction and Development (IBRD), the International Development Association (IDA), the International Finance Corporation (IFC) and the Multilateral Investment Guarantee Agency (MIGA); and a non-financial institution-the International Centre for settlement of Investment disputes (ICSID).
} 
The major reason behind such a move was that the framework would be indispensable to avoid the repetition of disastrous economic policies that have contributed to the great depression of the 1930s. Since then, the two institutions, hereinafter referred as International Financial Institutions (IFIs), have become the most important actors in development and financial areas.

IFIs have tremendous importance for the realisation of economic development of developing countries. Particularly, IFIs have made a commitment in the global fight against poverty and meeting the time-bound objectives of Millennium Development Goals (MDGs). Although IFIs support developing countries in poverty alleviation through the MDGs and other programs, the issue of human rights in general and the right to development in particular is only rarely referred in their policies. ${ }^{13}$

The so-called Washington Consensus ${ }^{14}$ formalized in the Structural Adjustment Programmes (SAPs) of the 1980 s imposed conditionalities that require developing countries to make policy changes such as privatisation, trade liberalisation cuts in social subsidies and income support in order to get loans and financial support from IFIs. Even if SAPs are no longer the operational policies of IFIs, the remnants of these conditionalities are still pursued which have neo-liberal tendencies. It has been argued that these policies have adverse consequences in promoting the fulfilment of socio-economic rights by diverting resources that would have been allocated to realise socio-economic rights. ${ }^{15}$

The more recent Poverty Reduction Strategy Papers (PRSPs) that were introduced towards the end of the 1990 s have also failed to incorporate human rights as their operational policies. ${ }^{16}$ IFIs-financed projects have been implicated with human rights violations and led to counterproductive consequences in different countries without any meaningful economic redress to affected people. The focus of the research is thus to analyse the policies and Financed projects of the World Bank and IMF and their compatibility with human rights in general and RTD in particular.

\footnotetext{
$13 \quad$ B Ghazi The IMF, World Bank Group and the question of human rights (2005) 59-82.

14 The term was coined by John Williamson in his article 'The progress of policy reform in Latin America (1990), cited in Gahzi (note 13 above) 46.

15 See B Mundho Effects of structural adjustment policies and foreign debt on the full enjoyment of human rights, particularly economic, social and cultural rights UN Doc. E/CN.4.2003/10 (23 Oct. 2002); D Auguirre 'Restricted development: the entrenchment of structural adjustment and human rights law' (2006) 18 Sri Lanka Journal of International Law 1.

$16 \quad$ ME Salmon et al Casting the net wider: human rights, development and new duty-bearers (2007) 198.
} 


\subsection{Significance of the study}

The study will have contribution in analyzing the compatibility of the policies and operations of the World Bank and IMF with human rights. By articulating the notion of the RTD, it explores a different perspective of addressing human rights accountability for IFIs in the development process through the RTD paradigm.

It is hoped that the research will serve as a resource base for academics who are interested in the area of human rights and development. The fact that the African Charter is the only international instrument incorporating the RTD also makes 'academic investment' in the area worthwhile. It provides an opportunity to develop it and utilize it in legal discourse.

\subsection{Statement of the Problem}

For developing countries, few financial sources are available externally unless they receive an informal 'seal of approval' of their economic policies from the World Bank and IMF. The economic conditionalities adopted by these IFIs for the most part proved a failure. ${ }^{17}$ This entails socio-economic loss which erodes the right of states to ensure the RTD. ${ }^{18}$ But more importantly, they affect the socio-economic rights of individuals by dislocating resources of the state to other areas as dictated by IFIs. Under the umbrella of the RTD, many human rights such as the right to work, food, housing, social security and the right to the enjoyment of the highest attainable mental and physical health can be affected by the policies of IFIs such as by pushing states for privatization or cuts in government subsidies. ${ }^{19}$

Direct human rights violations occur through IFI-financed projects by disregarding international human rights standards. IFI-financed development projects have resulted in

$17 \quad$ F Cheru Effects of structural adjustment policies on the on the full enjoyment of human rights, UN Doc. E/CN .4 /1999/50 (24 February 1999) 16.

18 See Concluding Observation of the Committee on Economic, Social and Cultural Rights on Brazil 23/05/2003 E/C.12/1/Add.87.

$19 \quad$ (as above) 241. 
forced displacement of people, affected the rights of indigenous people and generally adversely affected the human rights of individuals. ${ }^{20}$

Nevertheless, no effective redress is given for people affected by these policies and projects. The research will discuss the source of human rights obligations of IFIs and thereby suggest different human rights accountability mechanisms through the RTD paradigm.

\subsection{Objectives}

The research has the objective to:

- elaborate some of the conceptual controversies surrounding the meaning of the RTD;

- show how RTD can be used in international human rights law discourse to address human rights accountability issues for the policies and operations of IFIs;

- show that development and human rights should be compatible and IFIs should take in to account human rights issues, including the RTD;

- discuss the compatibility of the policies of IFIs such as SAPs and Poverty Reduction Strategy Papers (PRSPs) from the perspective of the RTD; and

- Suggest possible human rights accountability mechanisms for IFIs.

\subsection{Methodology}

The research will be primarily based on secondary sources such as books, articles, websites and other materials. Some case studies of countries affected by the policies and operations of IFIs will also be covered in the research. Moreover, the research will look into the normative framework on RTD including the Declaration on the Right to Development, and Articles of Agreement of the IFIs. 


\subsection{Hypothesis}

The research is based on the assumption that although IFIs have the purpose of helping developing countries to realize RTD, their policies and projects have adversely affected the realization of the RTD, and the enjoyment of human rights in general.

\subsection{Limitation of the study}

The research will focus on the policies and operations of the IFIs and their compatibility with the RTD. Because of this, other factors such as domestic socio-political circumstances and international factors such as the rules and policies of the World Trade Organisation and the UN at large will not be covered.

\subsection{Literature survey}

Arjun Sengupta is perhaps one of the most notable scholars who demonstrated the link between development and human rights. ${ }^{21}$ Other scholars also include Amartya Sen ${ }^{22}$, Stephen Marks ${ }^{23}$, Philip Alston $^{24}$ and Akinola Aguda ${ }^{25}$ who have also written on the link between development and human rights. However, little has been written to utilise the RTD in more concrete terms for IFIs human rights accountability mechanisms, to which this research is aimed at.

\subsection{Overview of chapters}

The paper has six chapters. The first chapter introduces the reader to the general framework of the research. The interdependence of concepts such as development, human rights and

${ }_{21} \quad$ UN appointed Independent Expert on the Right to Development, see A Sengputa et al (eds) 'Reflections on the right to development' (2005); A Sengupta 'Implementing the right to development' in N Schrijver \& F Weiss (eds) International law and sustainable development: principles and practices (2004) 15.

22 A Sen Developmnt as freedom (1999).

23 S Marks 'Making space for new human rights: the case of the right to development' (1998) 1 Harvard Human Rights Year Book 3.

$24 \quad \mathrm{P}$ Alston The right to development at the international level (1979); P Alston \& M Robinson (eds) Human rights and development: towards mutual reinforcement (2005) 46.

25 TA Aguda Huma rights and the right to development in Africa (1989). 
democracy is discussed in Chapter two; while doing so, two country case studies are presented that would give the reader background to the research. Chapter three deals with the impact of IFI policies and on human rights and the source of their human rights obligations. Chapter four sets out the legal framework on the right to development and its implications for IFIs. Chapter five deals with human rights accountability mechanisms that are available in the internal institutional framework of IFIs and external mechanisms such as the UN supervisory bodies. The last Chapter, Chapter six, gives the conclusion and recommendation of the research. 


\section{Chapter Two}

\section{The link between development and human rights}

\subsection{Introduction}

The beginning of the $21^{\text {st }}$ Century marked an increasing emphasis and acknowledgement of the relationship between human rights and other related fields such as development, democracy and good governance. ${ }^{26}$ This was also reiterated during the UN Millennium Summit. ${ }^{27}$ Within the UN, the United Nations Development Programme (UNDP) adopted its policy of integrating human rights with sustainable human development in 1998. Subsequently, beginning from 2000, the human development reports of the UNDP affirmed that human development is essential for realizing human rights in general and the right to development in particular.

Despite these global trends, IFIs still remain reluctant to integrate human rights in their institutional framework. The few attempts to integrate human rights that have been made by these institutions are ad hoc and ambiguous. The effect of this has been that IFI-financed projects have led to counterproductive consequences without adequate redress to affected people. The paper will discuss two country case studies that illustrate how IFI-financed projects can lead to human rights violations. Before doing so, however, the paper first deals with the nexus that exists between development, human rights and democracy.

\subsection{Development-democracy -human rights nexus}

Although there are differences of opinion on the extent and role of the state in economic affairs, the general understanding is that democracy is essential for the protection of human rights and well functioning state structure. Empirical research conducted has also shown that democratic governance is associated with better socio-economic performances. ${ }^{28}$ The UNCHR in its fiftyfifth session in 1999, also recognized the existence of a right to democracy by stating that

\footnotetext{
$26 \quad$ M Sepulveda et al (eds) Human rights reference hand book (2004) 399.

27 United Nations Millennium Declaration A/RES/55/2 (18 Sep. 2000).

28 A Sen Development thinking at the beginning of the 21st Century (1997) 13 -16.
} 
'democracy, development and respect for all human rights and fundamental freedoms are interdependent and mutually reinforcing.' 29

In 1998, the World Bank through its Finance and Development Section conducted a research by a group of highly qualified economists entitled 'Civil Liberties, Democracy and the Performance of Government Projects'. ${ }^{30}$ The major finding of the research was that the extent of civil liberties in a country affects the performance of IFI-financed projects. It was found that there is a strong link between the extent of civil liberties enjoyed in a country and the performance of World Bank-financed projects. ${ }^{31}$

Another study conducted in 1995 found that from the 121 donor-financed water projects, those that were highly participatory were successful 68 percent of the time; on the other hand projects with little or no participation with the beneficiaries of the projects were successful only 10 percent of the time. $3^{2}$

These findings have significant implications for IFIs-financed projects and their general approach to policy decisions. Loan decisions, project performances and the general policy trend of IFIs should integrate the notions of participation, respect for human rights, accountability, transparency and other elements of a human rights-based approach to development all of which are significant in ensuring the realization of the RTD.

This interrelated nature of democracy, governance and development strengthens the argument that IFIs should integrate these interrelated notions in their institutional framework. Nevertheless, as the subsequent discussions illustrate, the IFIs are far from taking a clear approach towards their role in the promotion and protection of human rights.

\subsection{Absence of a link between IFIs and human rights}

The World Bank and IMF have generally been reluctant to integrate human rights norms in their institutional framework. Although IFIs are making comprehensive plans for poverty

\footnotetext{
$29 \quad$ Sepulveda (note 26 above) 405.

3о I Jonathan et al 'Civil liberties, democracy, and the performance of government project' (1997) 11 World Bank Economic, Review 219-242.

$31 \quad$ (as above) 169 .

$32 \quad$ I Jonathan et al 'Does participation improve performance? establishing causality with subjective data' (1995) 9 World Bank Review.
} 
alleviation, which in itself has strong human rights dimension, they have not taken any joint position on the issue of human rights. Strictly speaking, there are no references to human rights in the mandate of the two institutions. They have considered human rights as political and internal matters of states. 33 Both the constitutional documents and operational policies of the IFIs which serve as terms of reference for IFIs have no explicit reference to human rights.

With respect to the World Bank, over time functional necessity and experience have shifted its lending focus from an exclusive economic focus on its development projects to a concern with general policy environment and social equity. ${ }^{34}$ Nevertheless, no single operational policy of the Bank exists that address the question of human rights. The only explicit reference to human rights is found in the Bank's Operational Directives on Indigenous Peoples. 35 The IMF also remains more reluctant to integrate human rights in its institutional framework and largely rejects their role in influencing its mandate. ${ }^{36}$

With respect to the RTD, the WGRTD has recommended repeatedly the importance of IFIs in realizing the RTD. The4th Report of the Independent Expert on the Right to Development has in this regard stated that although IFIs sponsored projects are not explicitly against the notion of the RTD, these institutions have not specifically recognized the link between human rights and development. ${ }^{37}$ The IFIs have not integrated the notion of the RTD in their policies and operations insisting that the general policies they adopt and their operations such as poverty alleviation are consistent with human rights.

Because of their lack of clear approach to human rights, often IFIs have been implicated with human rights violations by disregarding international human rights standards. These include, forcible resettlement of local inhabitants under physical threat and without proper compensation; $3^{8}$ environmental damages and the destruction of indigenous populations caused by private companies engaged in construction of oil pipe line that have been backed by IFIs. Bradlow also specifically points out some of the rights that can be implicated by the operations

\footnotetext{
$33 \quad$ Ghazi (n 13 above). 111.

34 DD Bradlow \& C Grossman 'Limited mandated and intertwined problems: a new challenge for the World Bank and the IMF' (1995) 17 Human Rights Quarterly 416.

$35 \quad$ World Bank operational Directive 4.20 on Indigenous Peoples (1991).

$36 \quad$ Salmon et al (note 16 above) 157.

$37 \quad 4^{\text {th }}$ Report of Independent Expert on the RTD, Mr Arjun Sengupta UNCHR E/CN.4/2002/WG.18/2 (2001) para $51 \& 52$.

$38 \quad$ See General Comment No. 7 para 18.
} 
of IFIs. ${ }^{39}$ These include the right to due process; freedom of association and expression; participation in government; right to work; right to health; right to education; right to food and right to housing.

\subsection{Case studies}

The lack of clarity in the approach of IFIs towards human rights has had negative effects in the enjoyment of human rights. To have a sound understanding of the negative impact of IFI activities on human rights, two cases studies are presented below. Although indirect violations of human rights equally occur through the imposition of neo-liberal economic policies, the impact of IFI-financed projects gives the reader a more vivid picture to the background of the research. The implications of IFIs' policies on human rights will be dealt in detail in Chapter three.

Projects can be defined as a deliberate, planned intervention by outside agencies into the lives of people usually by altering their physical and social environments.40 Projects financed by IFIs have served as important vehicles for development. Nevertheless, some of these development projects have been reckoned as 'development tragedies'41 because of the pervasive violation of human rights that is accompanied by them. As the Committee on ESCR points out "many activities undertaken in the name of development have subsequently been recognized as illconceived and even counterproductive in human rights terms.' 42

The Case of the Chad-Cameroon Pipe Line Project and the Lagos Drainage and Sanitation Project of Nigeria are relevant cases studies, particularly because express human rights violations allegations were made in both cases. These cases, however, by no means present exhaustive country case studies, yet they provide typical cases of issues that come to the fore while dealing with development and human rights issues.

$39 \quad$ DD Bradlow 'The World Bank, IMF and human rights' (1996) 6 Transnational Law and Contemporary Problems 59.

$40 \quad$ Paul (n 20 above) 20.

$41 \quad$ (as above) 19.

$42 \quad$ General Comment No. 2 Para 7. 


\subsubsection{The Chad-Cameroon Pipe Line Project (CCPP)}

The Chad-Cameroon Pipe Line Project (CCPP) is the largest energy infrastructure development project in Africa involving an estimated cost of US \$ 3.7 billion. The CCPP involved a consortium of three major private actors consisting of Exxon Mobile (US), Petronas (Malaysia), and Chevron (US). These three companies were granted a 30-year concession to undertake the development of oil fields. It involves the drilling of 300 oil wells in the Doba region of Southern Chad and the construction of an $1100 \mathrm{Km}$ long export pipeline through Cameron to an offshore loading facility. The project started to run after a lengthy negotiation which ended in agreement in 1988.43

Although the contribution of the World Bank to the total project cost is limited, its involvement was crucial not only in securing the funds but also in securing support of external actors, including the oil companies. The Bank acted as 'a lender and moral guarantor'44 to the international consortium operating in the project.

The CCPP was heavily criticized by NGOs and outside observers including prominent scholars on human rights. 45 This was largely due to the fact that Chad was ruled by one of the most authoritarian leaders in the continent, Deby and that the implementation of the projects did not take international human rights standards.

In this case study the author will highlight two major points in relation to the CCPP. Firstly, the general human rights violation in relation to the performance of the project and the response of the World Bank; and secondly, the problems in relation to the management of the oil revenues derived from the project.

In Chad, the government of president Deby had been taking repressive actions, particularly against the population living in the oil producing regions. The government's human rights

\footnotetext{
43 A Delescluse 'Chad-Cameroon: a model pipeline?' (2004) 5 Georgetown Journal of International Affairs 43.

$44 \quad$ GH Uriz 'To lend or not to lend: oil, human rights and the World Bank's internal contradictions' (2001) 14 Harvard Human Rights Journal 198.

$45 \quad$ JC Owens 'Government failure in Sub-Saharan Africa: the international community's options' (2003) 43 Virginia Journal of International Law 197; GH Uriz ' The application of the World Bank standards to the oil industry: can the World Bank Group promote corporate responsibility?' (2002) 28 Brooke Human Rights Journal 77, see also Uriz (n 44 above).
} 
record was poor; extrajudicial killings, torture, and rape were common. This state of affairs continues to be pervasive in the country until now. ${ }^{46}$

In May 2001, the local community represented by Mr Yorongar, opposed the project by contending that the CCPP constituted a threat to the local communities and that proper consultation had not taken place and that the performance of the project violates their human rights. They took their case to the World Bank Inspectional Panel by invoking the right to life, healthy environment, to fair and equitable compensation, proper resettlement place, to work, to respect for their custom and burial places, to social well being and to public consultation. The community contended also that there had not been any respect for human rights in the country since president Deby took power. They also stated that massive human rights violations had occurred, particularly in the oil production zone.

The Management of the World Bank (the Executive Directors) responded by stating that human rights violations were only relevant to the work of the Bank if they had 'a significant economic effect on the project.' In the specific case, it stated that 'the project can achieve its developmental objectives'. ${ }^{47}$ This same position was adopted by the Inspection Panel.

The response of the Inspection Panel and the management reaffirms the ambivalent nature of the Bank in its approach to human rights. The lack of clear approach on human rights becomes a bottleneck to integrate human rights in the institutional apparatus of the Bank.

With respect to the management of the oil revenue, the objective of the loan agreement between the Government of Chad (GOC) and the Bank was to make sure that it was used for poverty reduction. To ensure the use of the loans for this purpose, the Petroleum Revenue Management Law (PRML) was agreed between GOC and the Bank on mutual terms. The PRML provides that the majority of the revenue from the project be spent on public health and social affairs, education, infrastructure, rural development, environment and water resources. It was also agreed under the PRML that 10 percent of the revenue was to be saved for future generations. Nevertheless, the PRML does not determine the percentage of distribution of revenue among the different sectors.

The allocation of the revenue on social services and its management had problems from its inception. First, there was no concern for ensuring support to institutions of governance such as

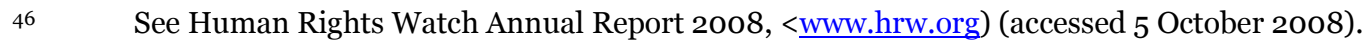

47 Inspection Panel, Investigation report on Chad-Cameroon Petroleum and Pipeline Project (17 July 2002 ) para 12.
} 
courts, human rights institutions, and the justice sector in general. Second, there was no guarantee that the revenue will be used for the stated purpose of poverty reduction as there was no effective management and hence it largely depended on the political will of the GOC. ${ }^{8}$ The government may use huge amount of the revenue to make sure that political opponents are destroyed by strengthening its military might and security sector.

In 2006, GOC changed most of the operational provisions of the PRML by stating that it does not meet the current demand of the state. The new law replaced the focus of the budget from social services to that of strengthening security and the military. President Deby used US \$ 4.5 million dollars from the consortium to purchase military equipments. The government also completely dislocated 10 percent of the revenue of the oil that was supposed to be used for future generations. 49

After initial suspension of Funds by the Bank, agreement was reached again between the two sides. Nevertheless, later in September 2008, the Bank again suspended its loans by stating that adequate resources were not allocated to social services that are crucial for poverty reduction. $5^{\circ}$

The above case study illustrates the ambivalence of the Bank's position with respect to human rights. If coherent and clear framework of IFIs' approach to human rights was put in place, such issues would have been solved by giving due recognition to human rights in a consistent manner. IFIs should make sure that the loans that give to governments are not used for further perpetrating human rights violations and strengthening despotic regimes. They have also the duty to ensure that projects are carried out in loan recipient countries by adhering to international human rights standards.

\subsubsection{The Lagos Drainage and Sanitation Project-Nigeria}

The purpose of the project which was financed by the World Bank was to improve the drainage system in parts of Lagos that suffered from regular drainage problems due to heavy rains. The project involved the removal of a number of shelters built by poor dwellers. All the dwellers were in principle to be resettled and properly compensated

\footnotetext{
$48 \quad$ FG Isa \& De Feyter (eds) International Protection of human rights: achievements and challenges (2006) $590 \& 591$.

$49 \quad$ Uriz (n 44 above).

5o Press Release No: 2009/o73/AFR http://go.worldbank.org/LNOXOH2W50 (accessed 7 Oct. 2008).
} 
The Executive Directors of the World Bank granted the loan to the government of Nigeria on 17 June 1993, five days before the presidential elections took place. The local community supported by one of the leading human rights NGO in Africa, Social and Economic Rights Action Centre (SERAC) complained against the Bank by stating that the military government of Nigeria and the Bank failed to consult with the affected parties. They specifically stated that the demolition of homes and destruction of properties constituted a massive violation of the right of victims to adequate housing, education, adequate standards of living, security of a person, a healthy environment, food, health, work, respect of dignity, freedom of movement, family life, water, privacy, information and the right to choose one's own residence. Other allegations also include police brutality, and gender discrimination related with the performance of the project. ${ }^{1}$

The response of the Bank's management consisted of a denial that human rights violations had occurred. On the other hand the management conceded that it did not have the capacity and the resource to observe every activity that happened while the project was being implemented. The management also stated that many of the alleged violations such as forced evictions were unrelated to the Bank's financed activities and hence were the sole responsibility of the Nigerian government. $5^{2}$

The Inspection Panel largely took the same position with the management by stating that most of the allegations were exaggerated or untrue. However, the Panel criticized the Bank for overtly relying on government officials to conduct the consultation with the affected communities and closer supervision should have been made by the Bank.

De Feyter also emphasizes on this point by stating that the continued ignorance of the Bank to the political context can be evidenced in its reliance on state officials to conduct the whole process of consultation.53 Under the then president Babangida, who was one of Africa's repressive regimes, officials and the whole political system demonstrated that they did not value participation of communities in political or project performance.

Although human rights violations related with the project were evident, affected individuals were not able to effectively assert their claims of human rights violations through the Inspection Panel. Because of the ambivalent nature of its position on human rights, the Bank has failed to

\footnotetext{
$51 \quad$ Isa \& De Feyter (n 48 above) 584.

52 The management stated: 'in any case, the Bank does not have the authority to discipline officials of the Lagos state department.'

$53 \quad$ Isa \& De Feyter (n48 above) 585.
} 
give any meaningful redress to human rights violations alleged by affected people. IFIs have the responsibility to ensure that the loans that they provide to governments do not lead to counterproductive consequences by violating the fundamental human rights of individuals.

In general, the CCPP and the Lagos Drainage and Sanitation Project illustrate some of the adverse effects of IFI-Financed projects on human rights. IFIs should integrate international human rights standards to ensure that their financed projects do not lead to violation of human rights. International human rights must be seen as essential, interdependent 'ends and means of development'.54 The basis of the right to development is also aimed at realizing basic rights through development. Any development process that is associated with the violations of human rights by definition violates the RTD. If IFIs do not adopt a clear approach towards their role in the protection and promotion of human rights, their financed projects can be counterproductive to ensuring the RTD.

\subsection{Conclusion}

The importance of the link between development and human rights calls for increased emphasis to integrate the two notions. IFIs as one of the major agents of the development process, particularly in developing countries, need to acknowledge this interdependence. The lack of explicit reference to human rights in their constitutional documents and their operational policies seriously undermines efforts to make human rights and development compatible.

The CCPP and the Lagos Drainage and Sanitation Project illustrate how development projects can lead to counterproductive consequences unless there is a clear framework on human rights. The few attempts made to internalize and mainstream human rights in IFIs are efforts made to soften the sharp neo-liberal profile of the two institutions and can only be described a mere window dressing. Thus, explicit recognition and integration of human rights principles is needed to effectively assess the impact of their policies and operations on human right.

The impact of IFIs becomes even more pervasive when these institutions impose neo-liberal economic policies that have long term and wide ranging human rights implications. The discussion of the next Chapter focuses on the impact of the policies of IFIs on human rights, particularly socio-economic rights and the source of their human rights obligations.

$54 \quad$ Paul (n 20 above) 32. 


\section{Chapter Three}

\section{IFIs and their policy implications on international human rights law}

\subsection{Introduction}

In an interesting article Stephen Marks illustrates the importance of focusing on structural violations of human rights that happen in the name of development. 55 His contention is that much of the human rights discourse had focused on short-term results rather than structural problems which would have wider and long term consequences. Today widespread deprivation of economic, social and cultural rights is largely the consequence of a global system that structurally disadvantages millions of people. ${ }^{56}$

The imposition of neo-liberal economic policies through the SAPs has had adverse consequences on the enjoyment of socio-economic rights. Although, the later PRSPs were in principle supposed to be country-driven, the remnants of the SAPs still continue to manifest and for the large part the PRSPs remain adjustment-oriented. 57 The Chapter looks into the impact of these policies on the enjoyment of socio-economic rights and the source human rights obligations of IFIs.

\subsection{Modus Operandi of IFIs}

Both the World Bank and the IMF are governed by Board of Governors that meets usually once a year. An Executive Board (also called Executive Directors) which receives its powers from the Board of Governors carries out the day to day activities of the two institutions through its internationally recruited stuff. The IMF consists of 24 Executive Directors ${ }^{5}{ }^{8}$ while World Bank

\footnotetext{
$55 \quad$ Marks (n 23 above) 3.

$56 \quad$ BA Andreassen \& S Marks (eds) Development as a human right: Legal, political and economic dimensions (2006)96.

$57 \quad$ See UNCTAD, the Least Developed Countries Report 'Escalating the poverty trap' (2002) IV-IX.

58 Eight executive directors represent individual countries: China, France, Japan, Russia, Saudi Arabia, the United Kingdom and the United States; sixteen other Executive Directors each represent groupings of the remaining member states.
} 
consists of 22 Executive Directors. The Executive Directors have the power to make decisions on policy issues and all loans made by the two institutions.

Since their inception, the IFIs have appointed their leaders in non-transparent manner in case of the IMF its managing director and the World Bank - a President. For more than 50 years, the presidency of the World Bank has been reserved for an American and the managing directorship of the IMF for a European. Currently, the President of the Bank still remains to be an American while the Bank's Managing Director is a European. 59

Unlike the UN, the IFIs do not operate in the principle of one-country-one-vote principle; they follow a weighted voting system. The strength of the vote of a member state is determined by its quota which in turn is dependent on global economic power. Thus, in times of deadlock to reach important decisions, the richer countries would have the power to decide on key policy issues. The quota also determines the amount of money that a state can borrow from the IFIs financial resources. 60

With respect to their financing operations, IFIs require a set of preconditions, which are labeled as conditionalities, before the borrower countries can get loans. Conditionalities have two major purposes. These include, to ensure that the borrower country be able to repay the debt and to make sure that the difficulties which gave rise to the loans are addressed.

Conditionalities can be categorized into two; economic conditionalities and political conditionalities. Economic conditionalities require borrower countries to take economic measure such as privatization; reduced public expenditure, particularly on social services; trade liberalization etc with the aim of increasing economic growth. While political conditionalities refer to non-economic conditions such as promoting good governance, democracy and environmental protection. ${ }^{61}$

59 Currently the President of the Bank is Mr. Robert B. Zoelik, an American by nationality. See <http://go.worldbank.org/IHDUWCAI20> (accessed 8 Sep. 2008); while the Managing Director of the IMF is Mr. Dominique Strauss-Kahn, French by nationality < http://www.imf.org/external/np/omd/bios/dsk.htm $>$ (accessed 10 Sep. 2008).

60 As of march 2008, the IMF's total quota was about US $\$ 357.3$ billion <http://www.imf.org/external/np/exr/facts/quotas.htm $>$ (accessed 15 Sep. 2008).

$61 \quad$ SI Skogly Human Rights obligations of the World Bank and the International monetary Fund (20001) $23 \& 24$. 
It is argued that economic conditionalities, as reflected in the SAPs and to some extent in the PRSPs, are incompatible with right of states to design appropriate economic policies and hence violate the RTD. Moreover, they have for the large part proved a failure in economic terms; the effects of increasing poverty and the deterioration of socio economic rights of individuals have been associated with them. However, political conditionalities are important to ensure the promotion and protection of human rights and the initiative taken by IFIs in this regard should be strengthened.

\subsection{Structural Adjustment Programmes (SAPs)}

The SAPs were conceived as a result of the debt crisis that heavily affected developing countries towards the end of the 1970s. As the division of labour between the World Bank and IMF became narrower, the two Bretton Woods Institutions moved into more programme lending and the conditions pertaining loans and credits became stricter and more comprehensive. These sets of conditions combined with the transfer of financial resources which became institutionalized in the IFIs, are labeled as SAPs. The SAPs were aimed at putting the economy of developing countries back on a path of sustainable growth by solving macro-economic crisis. ${ }^{62}$

It has to made clear that the term SAPs denotes a variety of schemes envisaged by IFIs with respect to their financing conditionalities. The early SAPs of the World Bank were called Structural Adjustment Lending (SAL) and were aimed at economy-wide reform conditions. The use of SAL increased in the early 1980 s and reached its peak in 1984. Subsequently, the Sectoral Adjustment Loans (SECAL) were introduced. However, SALs have continued to operate in the 1990 s and in 1998 the Bank approved 37 adjustment operations. ${ }^{6} 3$

Similarly, the IMF introduced SAP lending in the early 1980 s and this was formalized later under two schemes; the Structural Adjustment Facility (SAF) in March 1986 and the Enhanced Structural Adjustment Facility (ESAF) in December 1987.64

Even though the above different types of SAPs are not identical, there are some elements which are common to all SAPs. These include trade liberalization, abolishment of subsidies, devaluation of local currencies, privatization and reduced public expenditure. 65

\footnotetext{
$62 \quad$ (as above)20.

63 (as above ) 16 .

64 <http://www.imf.org > (accessed 22 Sep. 2008)
} 
The SAPs were heavily criticized by academics and there are a number of studies that show that these programmes have led to severe deterioration in the standards of living and adversely affected the enjoyment of socio-economic rights. ${ }^{66}$

Although the failure of the SAPs in economic, social and political dimensions has been proven, the IFIs still pursue these policies. As the UN Working Group on the Effects of Structural Adjustment Programmes points out 'what started out as SAPs aimed at the economic sector and debt management became a system for structuring the political and social organization of developing [countries] in order to make the world safer safe for investment.' ${ }^{67}$ The recent initiative of IFIs on the promotion of good governance though commendable also shows that there is more concern for investors than for human rights. ${ }^{68}$

These trends of IFIs that dictate neo-liberal economic reforms of developing countries as preconditions to get loans and debt relief, drastically affect the enjoyment of socio-economic rights of individuals by dislocating resources. This is because SAPs create enormous pressure on a nation's ability to design its economic and social policy, areas which are vital for the realization of socio-economic rights.

Reiterating this fact the UN human rights supervisory mechanisms have repeatedly stated the negative impact of SAPs on the enjoyment of socio-economic rights. ${ }^{69}$ The UN Committee on Economic, Social and Cultural Rights (Committee on ECSCR) in a series of its general comments has called up on IFIs to avoid imposing policies that lead to the deterioration of the enjoyment of socio-economic rights. For example, in its General Comment on the Right to health, by stating the unacceptable gross inequality between developed and developing countries the Committee on ESCR stated that IFIs should avoid structural impediments that occur through their lending policies, credit agreements, and SAPs. ${ }^{70}$ Similar assertions were made in

\footnotetext{
$65 \quad$ Skogly (n 61 above) 21.

66 M Chossudovsky The globalization of poverty (1997); J Oloka-Onyango 'Beyond the rhetoric: reinvigorating the struggle for economic and social rights in Africa' (1995-1996) 26 California Western International Law Journal 1. 67 Report of the Working Group on Structural Adjustment Programmes and Economic, Social and Cultural Rights UN Doc:E/CN.4/1995/51 (11 march 1999) para11.

$68 \quad$ Auguirre (n15 above) 6.

69 See UN Commission on Human Rights decisions E/CN.4/DEC/1997/103, E/CN.4/DEC/1998/102 and Resolution E/CN.4/RES/2001/27.

$70 \quad$ General comment No. 14 para 64 .
} 
the Committee's General Comments on the Right to Food, ${ }^{71}$ the Right to Water ${ }^{72}$ as well as the Right to Housing.73

Seen from the perspective of the RTD, SAPs are incompatible with the right of states to design appropriate socio-economic policies by themselves by violating the right of states to selfdetermination.

The two international covenants reaffirm the right of states to self-determination state:74

All peoples have the right to self-determination. By virtue of that right they freely determine their political status and freely pursue their economic, social and cultural development.

The two covenants unequivocally state that countries have the right to pursue socio-economic policies they deem appropriate taking account of their specific needs and circumstances. Reiterating this fundamental right of states, the DRTD states that states have the right to formulate appropriate economic policies aimed at ensuring the continuous improvement of all individuals. ${ }^{75}$ Thus, the SAPs that have been dictated by IFIs seriously undermine the right of states to self-determination and hence violate a fundamental principle of international human rights law.

SAPs directly challenge the notion of the RTD which demands inter alia accountability and participation. Through the external imposition of socio-economic policies, the right of states to follow the wishes of their people is highly compromised. SAPs destabilize self-determination in that key aspects of the right-based approach to development such as participation, empowerment transparency and accountability are set aside. As the UNCHR recognized, due to the effects of SAPs a state is often not able to allocate sufficient resources on social services even if the majority of the people support such a policy. ${ }^{7}$

The SAPs were largely non-participatory, undemocratic and were conducted in a nontransparent process. They have virtually been associated invariably with increased poverty, food

\footnotetext{
$71 \quad$ General Comment No. 12 para 41.

72 General Comment No. 15 para 60.

$73 \quad$ General Comment No. 7 para 18.

74 Article 1 CESCR and Article 1 ICCPR; see also Article 1 (2) DRTD.

75 Article 2(3) DRTD.

76 Commission on Human Rights, Resolution 2001/27 UN Doc: E/CN.4/RES/2001/27 para 2.
} 
insecurity and hunger, unemployment, restricted access to healthcare and education, and environmental destruction. 77

In general, SAPs undermine the right of states to pursue their own economic policies and have led to deterioration of the enjoyment of socio-economic rights there by violating the RTD. IFIs should not dictate economic policies which have detrimental effects on the enjoyment of socioeconomic rights in developing countries. The role of IFIs with respect to economic policies, if at all, should be advisory.

\subsection{Poverty Reduction Strategy Papers (PRSPs)}

Later on, the Heavily Indebted Poor Countries (HIPC) Initiative was jointly launched by the World Bank and IMF in 1996 in an effort to reduce poverty through debt relief. They were designed to address the disastrous consequences of the SAPs which had perpetuated economic strife and the violations of socio-economic rights. In order to qualify for debt relief through the HIPC Initiative, countries must prepare a wide-ranging Poverty Reduction Strategy Papers (PRSPs) that demonstrate their intention to use the freed resources for poverty reduction purposes. Nevertheless, the new scheme through the HIPC Initiative maintains the continuation of similar economic policies requiring SAP. 78

Although the PRSPs were designed to provide ownership and greater participation of policy making by recipient states, there are still problems that are faced when viewed from a human rights perspective. The operational policies and source books, which are considered as the terms of reference for the World Bank in the preparation of PRSPs, do not make any explicit reference to human rights. 79 Despite repeated criticism of IFIs to integrate human rights in clearer terms, their reluctance to explicitly integrate human rights in the development discourse still continues.

Although the IFIs are today engaged in the global fight against poverty and international commitment to achieve the MDGs, their response through the poverty reduction strategy still

$77 \quad$ S Ambrose 'Multilateral debt: the unbearable burden' (2001) 6 Foreign Policy in Focus 37. See also K Hansen-Kuhn \& D Hellinger Conditioning debt relief on adjustment: creating conditions for more indebtedness (1999).

$78 \quad$ Auguirre (n 15 above) 8.

79 World Bank, Operational Policies: Poverty reduction, OP 1.00 (2004) Washington DC, World Bank. 
remains adjustment oriented. ${ }^{80}$ Studies show that in the majority of the countries that have prepared PRSPs, the broad macroeconomic objectives such as privatization, downsizing, fiscal reform, restructuring and cost recovery are inconsistent with poverty reduction goals. ${ }^{81}$

Although PRSPs are ideally supposed to be country-driven, participatory and transparent, evidences demonstrate that in most countries examined, participation and transparency have not been respected. As Fantu Cheru points out, in the discussions of the social policy planning component of the PRSPs, parliamentarians, trade unionists and NGOs were excluded in the discussions of macro-economic policies. ${ }^{82}$ National ownership is also undermined by powerful external actors and consultants who impose key components the PRSPs. ${ }^{8}$ The report of the Independent Expert on the RTD also stated that the perception of developing countries in the PRSP process is that the process is imposed by IFIs than being country owned. ${ }^{84}$

The above discussions show that the PRSP process has failed to make any fundamental change to the SAPs or at least to force the IFIs to prove how their policies would help in empowering the poor and promote sustainable development. Although the initiative to integrate some important elements of the right to development such as participation, transparency and empowerment is commendable, it fails short of meeting the requirements set out in the notion of the RTD as will be explained in chapter four. As Mac Darrow has wittily described, the PRSPs are 'old wine in a new bottle'85 and they are largely the continuation of similar neo-liberal macro-economic policies that have adverse consequences in the enjoyment of socio-economic rights.

\footnotetext{
8o See UNCTAD (n 57 above).

81 RE Mazur 'Realization or deprivation of the right to development under globalization? Debt, structural adjustment and poverty reduction programs' (2004) Georgetown Journal 68.

82 F Cheru The Highly Indebted Poor Countries (HIPC) Initiative: a human rights assessment of Poverty Reduction Strategy Papers (PRSPs) (2001) UN Doc. E/CN.4/2001/56.

$83 \quad$ Participation and Civil Engagement Group (PCEG): Participation in poverty reduction strategy papers: a retrospective study <http://wwwworldbank.org/participation> (accessed 3 Oct. 2008).

84 Fourth Report of the Independent Expert on the Right to development, E/CN.4/2002/WG.18/2/Add.1 Para 49.

85 M Darrow Between light and shadow: The World Bank, the International Monetary Fund and international human rights law: (2003) 87.
} 


\subsection{IFIs as human rights duty-bearers}

The advent of globalization has generated a set of new duty-bearers in the area of human rights, specifically with reference to socio-economic rights in developing countries. In the contemporary world, development and poverty reduction are no longer the exclusive responsibility of the developing countries. ${ }^{86}$ The evolution of the international economy in recent decades has imposed a shared responsibility on a range of actors, notably IFIs.

The human rights obligations of IFIs emanates from two broad categories. The first includes norms related with the IFIs including their Articles of Agreement and treaties or agreements reached by the institutions with other entities. The second category includes norms external to these institutions such as international human rights law and general principles of public international law. ${ }^{87}$

\subsubsection{Articles of Agreement}

There are no references to human rights in the Articles of agreements of the IFIs. In fact, at first glance the Articles of Agreement of IFIs seem to suggest that they prohibit any engagement on member states' human rights activities. This is due to the fact that the main proposition of IFIs has been that they should not interfere in the political affairs of member states and that only economic considerations will be taken into account in their financing. Article IV (10) of the IBRD Articles of Agreement states:

The Bank and its officers shall not interfere in the political affairs of any member; nor shall they be influenced in their decisions by the political character of the member or members concerned. Only economic considerations shall be weighed impartially in order to achieve [its] purposes ...

Nevertheless, some point out that this does not restrict the World Bank from engaging in the protection and promotion of human rights. Ibrahim Shihata, former General Legal Counsel of the World Bank contends that the Bank has continuously developed its functions beyond the

\footnotetext{
$86 \quad$ (as above).

$87 \quad$ Isa \& De Feyter (n 48 above) 562.
} 
literal provisions of its articles of agreement; it only respects the overall purposes stated in the articles of agreement. 88

The general objectives and purpose of the Bank which inter alia aim at encouraging the development of productive resources and raising standard of living do not contradict with the idea of human rights. ${ }^{89}$ The Comprehensive Development Framework, launched by former President of the World Bank, James D. Wolfensohn also highlights the interdependence of all elements of development; social, structural, human, governance, environmental, macroeconomic and financial. ${ }^{\circ}$

Nevertheless, the emphasis of the Bank on political non-interference still poses a major problem in crucial matters that have human rights implications. Article IV (10) is aimed at issues of conditionality, and thus it means that the Bank should not refuse assistance because of prevailing human rights violations that occur in a borrower's country. ${ }^{11}$ The current position of the Bank on conditionality also bars human rights conditionality except in two very narrow scenarios. These include a UN Security Council action ${ }^{22}$ and where the economic consequences of human rights violations are so pervasive that it makes the project under consideration unfeasible. 93

Similar to the World Bank, the IMF's Articles of Agreement do not refer to human rights. Article IV of the IMF Articles of Agreement requires it to 'respect the domestic social and political policies of members, and in applying these principles ...pay due regard to the circumstances of members'. The IMF has interpreted this provision as a prohibition against considering political factors in its operations. ${ }^{4}$

Yet, one should note that the language of Article IV of the IMF Article of Agreement is less restrictive than that of the Bank's Article IV. The regular consultation it conducts with its member states is also based on Article IV of the Article of Agreement. Over time the IMF has

\footnotetext{
$88 \quad$ I Shihata 'Democracy and development' (1996) 46 International Law Quarterly 639.

$89 \quad$ Article 1 IBRD Articles of Agreement (27 December 1944)

$90 \quad$ See J Wolfensohn A proposal for a comprehensive development framework (1999) www.worldbank.org.cdf (accessed 16 Sep. 2008).

$91 \quad$ Isa \& Defeyter (n 48 above) $566 \& 567$.

$92 \quad$ See Article VI para 1 UN-IBRD Agreement.

$93 \quad$ Isa \& De Feyter (n 48 above) $566 \& 567$.

$94 \quad \mathrm{~J}$ Gold Political considerations are prohibited by Articles of Agreement when the Fund considers requests for use of resources, IMF survey (May 23 1983).
} 
expanded the range of issues in its consultations. Through Article IV consultations, the IMF may discuss such issues as the level of military expenditure, environmental issues, governance issues, and social safety nets. This broad consultation power of the Fund in Article IV suggests that it can exert influence over the human rights situation of member states.

Although there are some grounds in which IFIs can utilize their articles of agreement to protect and promote human rights, they need to have more explicit provisions in their constitutional documents that would give them clear mandate on human rights issues.

\subsubsection{IFIs as specialized agencies of the UN}

The incompatibility of the UN development agencies with human rights organs is one of the challenges that the UN has been facing for long. The rigid separation between the work of human rights organs of the UN and that of the development and financial agencies has been the major impediment to the existing lack of coherence of intergovernmental approaches to human rights. 95

IFIs are inter-governmental organizations capable of possessing rights and duties under international law. ${ }^{6}$ Accordingly, human rights obligations of IFIs may emanate from international agreements to which they are parties. In this regard the relationship agreements that IFIs concluded with the UN through which the IFIs obtained the status of UN Specialized Agencies has significant consequences.

An international organization which is willing to be recognized as a UN specialized agency has to be integrated into a formal relationship with the central bodies of the UN. Relationship agreements need to be approved by the UN General Assembly and in practice they are integrated to the UN through the ECOSOC. 97

\footnotetext{
$95 \quad$ Marks (n 23 above) 15.

$96 \quad$ Isa \& De Feyter (n 48 above) $561 \& 562$.

$97 \quad$ See Articles 57 \& 63 UN Charter; on relationship agreements see J Cot \& A Pellet (eds) La Charte des Nations Unies, Paris Economica (1991) 977-990, cited in Isa \& De Feyter (n 48 above) 575.
} 
Both the World Bank and the IMF have concluded relationship agreements which made them specialized agencies of the UN.98 This has important consequences in terms of the duties that would flow from such relationship, particularly from a human rights perspective.

The relationship agreements include obligations on behalf of specialized agencies of the UN to assist in achieving the objectives of international economic and social co-operation as defined in Article 55 of the UN Charter. This Article is significant in that it emphasizes universal respect for and observance of human rights as one of the principal purposes of the UN. 99 Article 55 is also significant from the perspective of the RTD. The provision emphasizes the right of states to selfdetermination, promotion of higher standard of living, social progress and development. One of the principal purposes of the UN according to the Charter is also the promotion of respect for human rights. ${ }^{100}$

The Committee on ESCR in its general comment has wittily summarized the human rights implications of obtaining a status of UN specialized agency. It stated:101

In negative terms this means that the international agencies should scrupulously avoid involvement in projects which, for example, involve the use of forced labour in contravention of international standards, or promote or reinforce discrimination against individuals or groups contrary to the provisions of the Covenant, or involve large scale evictions or displacement of persons without the provision of all appropriate protection and compensation. In positive terms, it means that, wherever possible, the agencies should act as advocates of projects and approaches which contribute not only to economic growth or other broadly defined objectives, but also to enhanced enjoyment of the full range of human rights.

IFIs are independent organizations that have their own functional independence. This allows them to conduct their activities independent of the UN.102 Nevertheless, what is required of IFIs by being specialized agencies of the UN is adherence to the fundamental principles of the UN Charter, one of which is the protection and promotion of human rights.

98 See Agreement between the United Nations and the International Bank for Reconstruction and Development, article IV(2), 16 UNTS 346 (1948); and Agreement between the United Nations and the International Monetary Fund, Article IV(2), 16 UNTS 328 (1948).

$99 \quad$ See also Article 1 para3 of the UN Charter.

$100 \quad$ See Article 1 para 3 \& preamble of the UN Charter.

$101 \quad$ General Comment No. 2 para 6.

102 See for example, Article 1 of the UN-IBRD Relationship Agreement (15 April 1948). 
Other commentators have also stressed the particular significance of Article 103 of the UN Charter. ${ }^{103}$ Article 103 of the UN charter states:

In the event of conflict between the obligations of the members of the United Nations under the present Charter and their obligations under any other international agreement, 104 their obligations under the present Charter hall prevail.

IFIs are entities established by international agreements of states. It follows that these agreements are subsidiary to the UN charter. In case of conflict between the obligations of member states in the UN Charter and that of constitutional documents, operational directives and general policies of IFIs, the former would prevail over the latter. As explained above the observance of human rights being one of the fundamental purposes of the Charter, any other agreement detrimental to the promotion of human rights would be void.

The International Law Commission has elaborated this provision by stating that the superiority of the Charter's provisions extends also to agreements between states, international organizations and states, and among two or more international organizations. As one of the fundamentals of the Charter is respect for human rights, it can be argued that IFIs have the obligation to comply with those duties as a matter of priority.

\subsubsection{IFIs as entities composed of states}

It is important to recognize the fact that IFIs are entities composed of states. Most of the countries who are members of the World Bank, (185 countries) ${ }^{105}$ and IMF (185 countries) ${ }^{106}$ are parties to international human rights treaties including the ICCPR and CESCR. Although IFIs have legal personality separate from their members, it is logical to argue that as entities composed of states, they have the legal duty to respect their human right obligations as laid down in the UN Charter to which they have a legal obligation.

The CESCR makes explicit reference to international co-operation and assistance for the realization of the rights enshrined in the covenant. ${ }^{107}$ It flows from this that there are extra- 
territorial obligations to co-operate for development internationally. This international obligation to co-operate can be disaggregated into obligations to respect, to protect and to fulfill. ${ }^{108}$

At the minimum, IFIs have the obligation to respect and protect already existing socio-economic rights. Their members, particularly those which ratified the CESCR, have an international obligation not to take retrogressive measures that would have the effect of affecting existing enjoyment of socio-economic rights. In this regard, the Committee on ESCR in its concluding observations on Norway has stated that the extraterritorial obligation to respect applies in the context of development co-operation. ${ }^{109}$

Decisions of IFIs on policy issues and loan grants are made by country representatives through the Board of Directors. In making decisions, they should not infringe the human rights obligations of any of their member countries that has undertaken international legal obligation to implement those treaties. The discussion in the introductory part of the Chapter has shown that often the infringement of human rights by a state party to international human rights instruments is due to the effect of imposed economic policies by IFIs. ${ }^{110}$

First, there exists a responsibility up on the IFIs to ensure that the policies they impose do not compel a developing state to breach its human rights obligations. But more importantly, IFIs as composed of states have their own external human rights obligations. For example, any measure affecting the right to health or the right to education is not only incompatible with the MDGs to which IFIs have subscribed but is also violating the CESCR by the state parties. ${ }^{111}$

The Committee on ESCR has made a series of recommendations on IFIs to respect international human rights law and to refrain from policies and activities that affect the enjoyment of socioeconomic rights. ${ }^{112}$ These assertions are implicitly recognizing the responsibility of the member states obligations to adhere to international human rights standards to which they have subscribed.

\footnotetext{
$108 \quad$ Salmon et al (n 16 above) $85,86$.

109 Committee on ESCR Concluding Observations: Norway, UN Doc.E/C.12/1/Add.109 (2005) para 35; see also Concluding Observations: Denmark, UN Doc.E/C.12/1/Add.102 (2004) para 5.

$110 \quad$ For an illustration of the adverse effects of privatization on the enjoyment of socio-economic rights, see also K De Feyter \& IG Isa (eds) 'Privatization and human rights in the age of globalization' (2005).

$111 \quad$ Salmon et al (n 16 1bove) 160.

112 See (n 70 above) and subsequent foot notes.
} 


\subsubsection{Human rights obligations of IFIs emanating from general rules of international law}

IFIs are intergovernmental organizations and hence subject to the general rules of international law. ${ }^{113}$ The International Court of Justice (ICJ) in its advisory opinion on interpretation of the agreement of 25 March 1951 between the WHO and Egypt case stated that as subjects of international law, international organizations are bound by 'any obligation incumbent up on them under general rules of international law, under their constitutions or under international agreements to which they are parties.'

Consequently, IFIs are subject to international human rights law to the extent that human rights law is incorporated in international custom or general principles of international law. In this regard it is important to note that elements of human rights law have attained the status of international custom and general principles of international law.

Among these principles, IFIs have the obligation to respect general rules of human rights law and not to violate or become complicit in the violation of human rights norms by actions or omissions attributable to them. This obligation arises from the premise that the powers and functions of intergovernmental organizations including IFIs should not be seen as to permit actions that are against general rules of international law and hence human rights law.

Although academics have elaborated some of the human rights norms that have attained the status of international customary law (jus cogens), it is more difficult when it comes to general rules of international human rights law. The ICJ has ruled that some acts such as genocide, wrongful deprivation of liberty, and racial discrimination constitute a violation of international law. ${ }^{114}$ It also stated that the right to self-determination had an erga omnes character. ${ }^{115}$ Skogly contends that most aspects of civil and political as well as social, economic and cultural rights have attained the status of general rules of international law. ${ }^{116}$

It is argued that the RTD as a reiteration of the fundamental human rights of individuals incorporated in the major international covenants can be considered as a general principle of international law. Although contentious during the initial adoption the DRTD, the subsequent

\footnotetext{
$113 \quad$ Isa \& De Feyter (n 48 above) 562.

$114 \quad$ Belgium $v$ Spain (1970( ICJ reports para 33\&34.

$115 \quad$ Portugal $v$ Australia (1995) ICJ reports 102. See also United States $v$ Iran (1980) para 43.

$116 \quad$ Skogly (n 61 above) 4.
} 
declarations, resolutions and decisions of UN human rights bodies, and international conferences have shown that there is a major consensus to respect the principles of the right to development. In this regard the WGRTD also has called up on 'IFIs [to] give the highest priority to an action-oriented approach to the right to development in its multi dimensional aspects'. ${ }^{117}$ John Dugrad also states that 'an accumulation of declarations and resolutions on a particular subject may amount to evidence of collective practice on the part of states' and hence may constitute a customary rule. ${ }^{118}$

In practice, there is also an implied recognition of IFIs in their obligation to adhere to the principles of the RTD. Both the World Bank and IMF are consulting with the WGRTD on how to integrate its elements in the development process. In this regard Former General Legal Counsel of the World Bank, Ibrahim Shihata states: ${ }^{119}$

The right to development as defined in [the Declaration on the Right to Development] is one human right which the World Bank has been promoting throughout its history, and which in fact is at the heart of all the institutions efforts.

Although the statement does not reflect the reality of the Banks approach towards the RTD and human rights in general, it has an important implication for the discussion at hand. It shows the existence of the necessary opinio juris (the intention to be bound) which is an important element to establish the existence of international customary rule.

As a concluding remark, it can be said that to the minimum, IFIs have the obligation to respec $^{120}$ existing human rights. Although, it may be difficult to extend the obligation of these institutions to fulfill human rights, at the very least their policies and financed projects should not deteriorate existing enjoyment of human rights, particularly socio-economic rights.

\footnotetext{
117 Inter-governmental Working Group of Experts on the Right to Development second session U.N.Doc.E/CN.4/1998/29; See also General Assembly Resolutions on the RTD, A/RES/54/175 (15 Feb. 2000) \& A/RES/6o/157 (23 Feb. 2006).

$118 \quad J$ Dugard International law: a South African perspective (2005) 34.

119 I Shihata The World Bank in a changing world (1991) 110; cited in De Feyter 'World development law: sharing responsibility for development'(2001)273.

$120 \quad$ My emphasis.
} 


\subsection{Conclusion}

IFIs as major agents of the globalization process have promoted policies and processes that are detrimental to the enjoyment of socio-economic rights. This process of globalization has generated a responsibility on IFIs to adhere to the fundamentals of international human rights law.

A closer scrutiny at the existing international human rights norms, principles of public international law and the internal rules of IFIs show that they have the legal duty, at the very least, to respect the observance of human rights.

The RTD provides additional opportunity in serving as a normative basis for the human rights obligations of IFIs. As a composite right incorporating other human right, it helps us in bringing human rights under one umbrella. Some of its unique normative components also become indispensable by providing a new perspective on human rights obligations of IFIs. This next Chapter illustrates the implications of RTD on IFIs. 


\section{Chapter four}

\section{The legal framework on the Right to development- implications for IFIs}

\subsection{Introduction}

The RTD provides a tremendous opportunity to strengthen the efforts of the international community to examine international human rights challenges in a wider and comprehensive context. It encourages interdisciplinary analysis of human rights and tries to fill in the inadequacy of the existing international human rights supervisory mechanism to address wider and comprehensive challenges. ${ }^{121}$

The Chapter will look into the normative framework of the RTD. By doing so, it elaborates the meaning of the RTD and the legal obligations flowing from it. More importantly, it will highlight the implications of the RTD paradigm in the development process and the Obligations of IFIs in ensuring its implementation.

\subsection{Legal framework}

In comparison to other rights that have been the subject of human rights discourse, the RTD has quite a recent history. It was conceived in an inaugural lecture at the International Institute of Human Rights in Strasbourg by former Senegalese jurist and head of UNHCR, Keba M'baye, in 1972. Beginning from its moment of inception, developing countries advocated for the inclusion of the RTD as a human right through the UN. This culminated in the adoption of the Declaration on the Right to Development (DRTD) in $1986^{122}$ which recognized the RTD as a fundamental principle of human rights. ${ }^{123}$

Although the legal foundation of the RTD was laid down in 1986, its genesis can be traced back to the Universal Declaration and the subsequent international covenants. The Universal

\footnotetext{
$121 \quad$ Marks (n 23 above) 7.

122 See DRTD (n 7 above).

123 VP Nanda et al (eds) World debt and the human condition: structural adjustment and the right to development (1993) 43.
} 
Declaration by proclaiming the right of individuals to be free from fear and want aspires for the creation of an international order where the human rights of individuals can be enjoyed to the fullest extent. These principles were later incorporated under binding international treaties that impose obligations on states to respect, protect and fulfill human rights. As a composite right that incorporates other rights, it can be said that the RTD was implicitly recognized in the international bill of rights.

\subsubsection{The Universal Declaration of Human Rights - a precursor to the right to development}

The Universal Declaration by incorporating civil and political rights as well as social, economic and cultural rights laid down the foundation to the concept of the RTD. In its preamble it reiterates the obligation of member states under the UN Charter to promote universal respect for and observance of human rights and fundamental freedoms. ${ }^{124}$ In its promise of 'larger freedom' it emphasizes on social progress and achievement of better standard of living. It aims at achieving a social and international order to ensure the realization of all the rights enshrined in the Declaration. ${ }^{125}$

By incorporating all categories of rights in the same category, the indivisibility of human rights and their universality is well articulated. The greatest achievement of the Declaration was in fact, its inclusion of economic, social and cultural rights. According to the Declaration economic, social and cultural rights are indispensable for one's dignity and free development of one's personality. ${ }^{126}$

The above issues have important elements that are related with the concept of the RTD. The incorporation of social, economic and cultural rights in particular serves a 'dual function of freedom and equality' to which the RTD tends to achieve. ${ }^{127}$ By emphasizing the significance of creating an international order where all human rights can be enjoyed to the fullest extent for all, it laid down the foundation for the content of the RTD. The two international covenants of 1966; International Covenant on Economic Social and Cultural Rights (CESCR) and

\footnotetext{
124 Universal Declaration of Human Rights, adopted 10 Dec. 1948, Preamble, para 6.

125 Premble, para 5 Universal Declaration.

126 Article 22 \& 25 Universal Declaration.

$127 \quad$ Andreassen \& Marks(n 56 above) 241.
} 
International Covenant on Civil and Political Rights (ICCPR) transformed the contents of the Declaration into legally binding treaties there by strengthening the enforcement of these rights.

\subsubsection{The Declaration on the Right to Development}

In 1977 the UNHCR adopted a resolution which for the first time formally recognized the RTD as a human right. The resolution called up on the Secretary-General to undertake a study on 'the international dimensions of the right to development as a human right in relation with other human rights based on international co-operation.' ${ }^{128}$

In 1979, the Secretary-General published a report which laid down the ethical and legal foundation for the RTD. The report states:129

[T] here are a variety of ethical arguments which may be considered to support the existence in ethical terms of a right to development. These include the fact that development is the condition of all social life, the international duty of solidarity, the duty of reparation for colonial and neocolonial exploitation, increasing moral interdependence, economic interdependence, and the cause of world peace, which is threatened by underemployment.

The report of the Secretary-General highlights the major reason behind the articulation of the notion of the RTD. It was a claim for global justice and equity. Developing countries felt that if human rights are to be realized for all, not only the nation state but also the international community at large should have the responsibility. The increasing interdependence among nations that came through the globalization of the world economy makes unilateral development endeavors fruitless unless backed by international co-operation. Hence, a concerted effort was needed to solve primarily the problem of poverty in developing countries through international co-operation not as a matter of charity but as a matter of responsibility.

In November 1979, the UNGA passed a resolution recognizing the right to development as a human right. ${ }^{130}$ Subsequently, the UNGA proclaimed and adopted the Declaration on the Right

\footnotetext{
$128 \quad$ UN Doc. E/CN.4/SR1389, 1392-98 (1977), Resolution 5 (XXXIII) para 4.

129 UN Doc. E/CN.4/1334 (1979). For further discussion on the ethical grounds of the RTD, see RY Rich 'The right to development as an emerging human right' 23 Virginia Journal of International Law 322 (1983).

$130 \quad$ General Assembly Resolution 34/46 (1979).
} 
to Development (DRTD) by a vote of 146 to 1 , with 8 abstentions. ${ }^{131}$ The adoption of the declaration showed the overwhelming support for the recognition of the right development as a human right. The single dissenting vote from the United States and all the eight abstentions came from the developed countries, showing the negative attitude of these countries towards the idea of the RTD.

The declaration includes 10 provisions which define the content of the right, the right holders and duty bearers. Development as defined in the declaration is a comprehensive process that goes beyond economics and covers social, cultural and political fields to achieve continuous improvement of the well-being of human beings. ${ }^{132}$ This definition differs from the traditional definition which views development as a simple expansion of GNP, industrialization or capital inflows. ${ }^{133}$ The traditional understanding that development is just an increase in GNP has thus been discarded, there by opening up this new conception. ${ }^{134}$

According to the declaration, the RTD refers to a process of development that leads to the fulfillment of all human rights through a rights-based approach that takes into account international human rights standards, ${ }^{135}$ participation, ${ }^{136}$ non-discrimination, ${ }^{137}$ accountability, ${ }^{138}$ transparency and equity in decision making and sharing the benefits of the process. ${ }^{139}$ Both a process of development and its objective are thus, important components of the RTD.

The emphasis given to the process of development as a basic component of the RTD is reflected in many of its provisions. For example, it states that development process should be the constant improvement of the well-being of the entire population and of all individuals, on the basis of their free and meaningful participation'. ${ }^{140}$ It further states that the purpose of development should be to ensure 'equality of opportunity for all in their access to basic

\footnotetext{
${ }_{131}$ The United States of America was the only country that casted a vote against the declaration while Denmark, Finland, Federal Republic of Germany, Iceland, Israel, Japan, Sweden and United Kingdom abstained. 
resources, education, health services, food, housing, employment, and the fair distribution of income....' ${ }^{141}$

The purpose of a development process, according to the declaration is thus aimed at the full realization of all human rights, i.e., Civil and political as well as social, economic and cultural rights for all individuals.

\subsubsection{The Vienna Declaration and Programme of Action}

The Vienna Declaration ${ }^{142}$ was a turning point for the general human rights discourse and the RTD in particular. It laid down an important precedent by stating that all human rights, i.e., civil and political rights as well as social, economic and cultural rights are universal, indivisible, interdependent and interrelated. Reiterating the significance of the RTD, the Declaration specifically states: ${ }^{143}$

The World conference on human rights reaffirms the right to development, as established in the Declaration on the Right to Development, as a universal and inalienable right and an integral part of fundamental human rights.

The Declaration was significant in that it reflected a fundamental consensus on the inalienable, universal and interdependent nature of human rights in general. This consensus was significant in that some countries that made reservations to the adoption of the DRTD and the United States, which casted the only single objection against the adoption of the DRTD accepted the RTD as a fundamental human right.

\subsubsection{The African Charter on Human and Peoples' Rights}

The ACHPR is the only human rights instrument that recognizes the RTD as a legally binding and enforceable right. The African Charter adopted the RTD as a human right long before the adoption of the DRTD by the General Assembly. As discussed in Chapter one it was also the product of an African intellectual that gave rise to the notion of the RTD. Because of this the RTD is considered as a unique African contribution to the international human rights discourse.

\footnotetext{
$141 \quad$ Article 8(1) DRTD.

142 Vienna Declaration (n 8 above).

143 Article 10 Vienna Declaration.
} 
The preamble of the Charter highlights the special emphasis given to the RTD by stating that it is 'essential to pay particular attention to the right to development' and both civil and political rights as well as social, economic and cultural rights cannot be dissociated from each other. ${ }^{144}$ Article 22 which spells out the normative basis of the RTD states:

All peoples have the right to their economic, social and cultural development with due regard to their freedom and identity and in the equal enjoyment of the common heritage of mankind. States shall have the duty, individually and collectively, to ensure the exercise of the right to development.

The inclusion of this provision in the Charter is significant to enrich the content of the RTD and its jurisprudence. The Commission in its land mark decision of the Ogoni land case ${ }^{145}$ stated that the state of Nigeria by failing to protect the people of Ogoni has violated their right to development.

State reports that are submitted periodically by the states parties also provide another opportunity for the Commission to monitor the compliance of member states to ensure the RTD. According to the guidelines of the Charter on state reporting, each state party has to show the efforts it has taken to ensure each of the rights incorporated under the Charter. ${ }^{146}$ In some of the state reports that the author consulted, some important elements of the RTD were reflected in their reports. ${ }^{147}$

It is also interesting to see that the RTD has been included in national constitutions of some African countries including Ethiopia. The Constitution of the Federal Democratic of Ethiopia (FDRE), inter alia states that the rights of the people of Ethiopia as a whole and each nation, nationality or people to improved living standards and to sustainable development. ${ }^{148}$ One of the most interesting parts of this provision also makes direct reference to essential elements of the DRTD. It states, 'nationals have the right to participate in national development and, in

\footnotetext{
$144 \quad$ Preamble, para 9 ACHPR.

$145 \quad$ Social and Economic Rights Action centre (SERAC) and Another v Nigeria (2001) AHRLR 60 (ACHPR 2001).

146 Artilce 62 ACHPR.

147 See the $3^{\text {rd }} \& 4^{\text {th }}$ Periodic Report of Algeria (2006); this report stated that the state was concerned with equitable distribution of the benefits of development and this was supported by statistical data on the measures taken to fulfill socio- economic rights. See also $8^{\text {th }}, 9^{\text {th }}$ and $10^{\text {th }}$ Periodic reports of the Democratic Republic of Congo (2007) para 208.

$148 \quad$ Article 43(1) FDRE constitution.
} 
particular, to be consulted with respect to policies and projects affecting their community.'149 This shows that the RTD can, indeed be included in binding human rights instruments both nationally and internationally.

In general, the work of the African Commission will have important contribution in the development of the jurisprudence of the RTD. It is important to note that the cross-pollination of international and regional human rights systems has made significant contribution to the general human rights discourse. As the only regional human rights system that incorporates the RTD, the international human rights system can benefit from this emerging jurisprudence.

\subsection{Subjects and duty-bearers}

In the beginning, developing countries were in favor of the idea of a RTD in the context of state rights only. ${ }^{150}$ This conception of the RTD as a human right has been opposed for fear of states claiming development as a human right. Because of this, it has been generally agreed that states have no human right. However, it does not rule out the possibility for states to be subjects of the RTD, as it also forms part of the principle of public international law. ${ }^{151}$

The current general understanding is that depending on the context different categories of entities can be the subjects of the RTD. These may include individuals, peoples and states. With respect to individuals, as much as they are the central subjects of the right to development, they also have a duty to ensure their right to meaningful political, social, economic and cultural development. ${ }^{152}$ Every human person has the duty to be able to develop his personality that would enable him to lead a worthy and dignified life. Individuals have also the duty to help their family and the larger community to ensure the RTD. Thus, they should be active participants in development planning as well as in all the processes of implementation.

Individual States are the traditional duty bearers in respect of human rights including the RTD. This traditional notion is also emphasized by the DRTD in that it makes it clear that states both

\footnotetext{
149 Artilce 43(2) FDRE Constitution.

$150 \quad$ J Makarczyk Principles of a new international economic order (1988) 186 cited in Chowdhury et al (eds) The right to development in international law (1992) 11.

${ }_{151}$ Paul JIM Waart Global consultation on the Realization of the Right to Development as a Human Right ER/RD/1990/Conf.15 (12 Jan. 1990).

152 Article 2(2) DRTD.
} 
individually and collectively ${ }^{153}$ have the primary responsibility ${ }^{154}$ to create national and international conditions favorable to the realization of the RTD. ${ }^{155}$ In the first place, the fundamental obligation for ensuring development lies within each nation state. It has the obligation to undertake all the necessary measures for the realization of the RTD and the progressive enhancement of the right. ${ }^{156}$

With respect to the collective duty of states, the DRD emphasizes the special status of developing countries in its provisions. ${ }^{157}$ It has to be made clear that much of the impetus for the adoption of the DRTD is centered on the needs of developing countries. ${ }^{158}$ The General Assembly of the UN also adopted the Charter of Economic Rights and Duties of States which reaffirmed the responsibility of every state to promote economic, social and cultural development of its own people and those of developing countries. ${ }^{159}$ These may include financial and technical assistance, providing better terms of trade, and transfer of technology to developing countries. ${ }^{160}$

The DRTD emphasizes the crucial importance of international co-operation. It states that states have the duty 'to co-operate each other in ensuring development and eliminating obstacles to development' ${ }^{\prime 161}$, to promote universal respect for and observance of all human rights and fundamental freedoms. ${ }^{162}$

By bringing all human rights in one category, the RTD adds new de lega ferenda obligations on the international community, including IFIs. Particularly, in respect of socio-economic rights

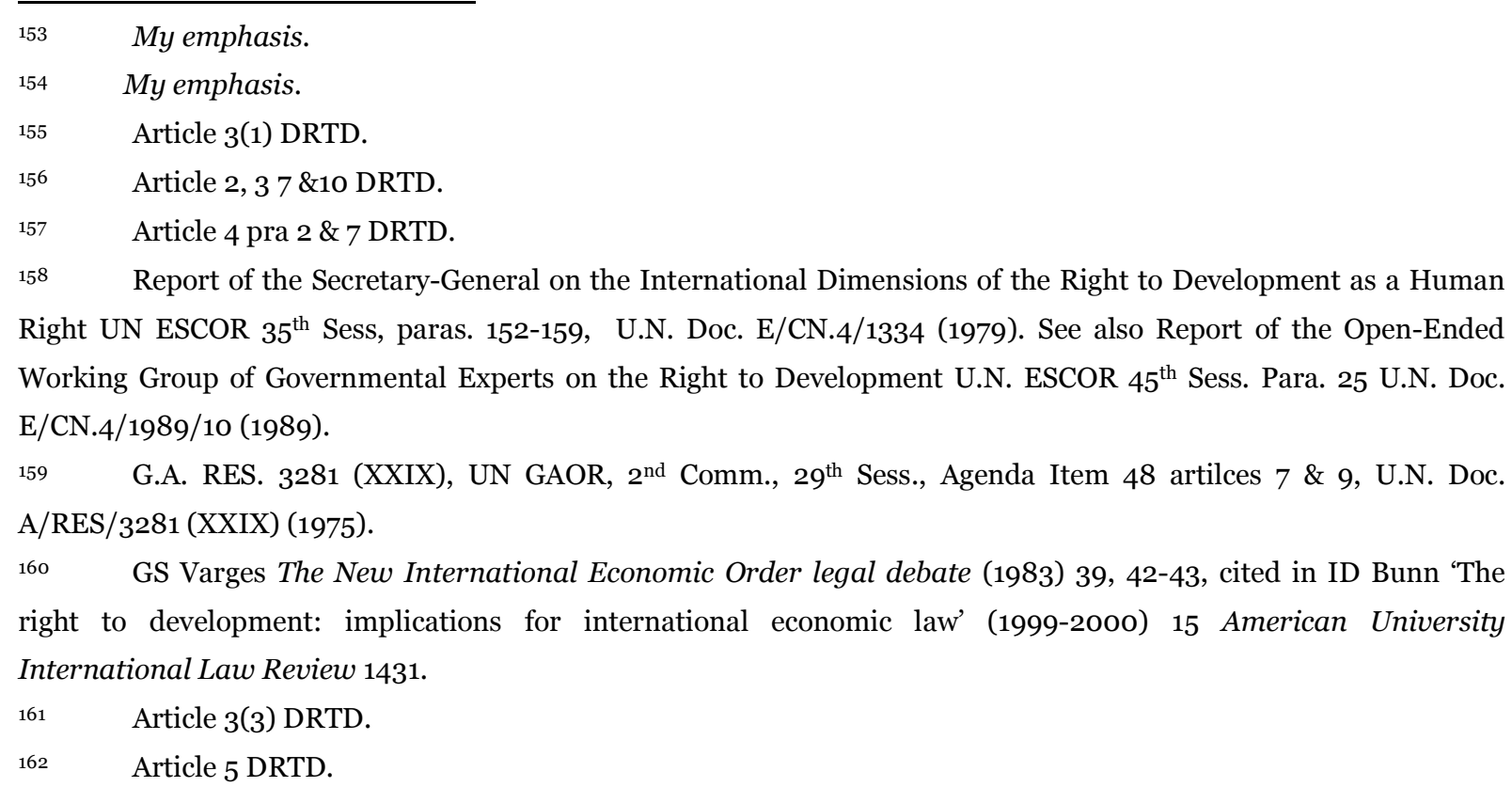


there is a collective duty for countries that have ratified the CESCR and by extension IFIs, to promote the fulfillment of socio-economic rights, but more importantly not to adversely affect the enjoyment of these rights. ${ }^{163}$ In its General Comment on the Nature of States Parties' Obligations, the Committee on ESCR stated that the phrase 'to the maximum of its available resources' was intended to include both resources existing within a state and those available from the international community. ${ }^{164}$ Explicit references to the duty of IFIs have also been made in a series of general comments of the Committee on ESCR. In its General Comments on the Right to health, on the Right to Food, the Right to Water as well as the Right to Housing. ${ }^{165}$

\subsection{Concerns of justiciability and feasibility}

Some scholars, including Mansell \& Scott ${ }^{166}$ have dismissed claims of the RTD as a hopeless utopian proposal' largely based on the belief that development and human rights are separate ideals. ${ }^{167}$ Yet, as shown in Chapter two be pointed, there is a growing consensus and concrete evidence to show that development and human rights are interrelated concepts.

Despite the fact that the RTD has been characterized as 'specifically African contribution to international human rights discourse', ${ }^{168}$ it has also faced criticisms from African scholars notably Issa Shivji ${ }^{169}$ and Rhoda Howard. ${ }^{170}$

There are two major questions that are raised against the RTD as a human right, namely that of justiciability and feasibility. In the following section the paper will highlight these arguments briefly. One has to acknowledge the fact that a right exists does not necessarily imply a legally enforceable claim against an identifiable object of a right. The RTD has identifiable duty bearers,

\footnotetext{
163 Article 2 CESCR.

164 General Comment No.3 para 13.

165 See (n 69 above) and subsequent foot notes.

166 W Mansel \& J Scott 'Why bother about a right to development? (1994) 21 Journal of Law and Society 171;

See also RW Perry 'Rethinking the right to development: after the critique of development, after the critique of rights' (1996) 18 Law and Policy 228.

168 BS Santos Towards a new common sense: law, science and politics in the paradigmatic transition (1995) 357, see also M Bedjaoui The right to development in international law: achievements and prospects (1991) cited in Perry (n 166 above) 228.

169 IG Shivji The concept of human rights in Africa (1989) 82, cited in Perry (n 82 above) 228.

${ }_{170}$ R Howard 'The full belly thesis: should economic rights take priority in over civil and political rights? evidence from Sub Saharan Africa' (1983) 5 Human Rights Quarterly 467-490.
} 
but the manner in which it is implemented is much more complex and depends on a comprehensive international framework fo

$\mathrm{r}$ its realization.

\subsubsection{The question of justiciability}

Similar to the arguments that are usually raised against socio-economic rights, much of the opposition against the notion of the RTD emanates from the non-justiciable nature of the claim. This criticism becomes even much stronger due to the comprehensive nature of the notion of the RTD itself and the declaratory nature of its normative content.

From a legalistic perspective, critics of the RTD contend that it was adopted only as a Declaration of the General Assembly and does not have any binding nature of a multilateral treaty. ${ }^{171}$ They point out that in other international human rights instruments states parties have obligations to protect, respect and fulfill different categories of rights. Donelly, ${ }^{172}$ one of the prominent critics on the RTD, has characterized the RTD as a 'search for unicorn' and contended that it is pointless within the framework of international legal argument. He noted that its language confuses rights with moral claims without indicating specific right-holders and duty-bearers.

The RTD is 'a conglomeration of rights' encompassing civil and political as well as socioeconomic rights.' ${ }^{173}$ Thus, from the traditional conception of justiciability it would be difficult to enforce these whole set of rights in some form of formalized and rigid judicial or quasi judicial body. Nevertheless, the RTD is a legally enforceable human right reaffirmed in DRTD and other numerous declarations and resolutions of the General Assembly and its subsidiary bodies. The manner in which this right may be implemented is something that is evolving under its WGRTD; yet it suffices to say that it is a legal right with identifiable duty-bearers. One has to also recognize that much of the international human rights mechanism is based on supervision rather than adjudication and hence the RTD can well fit under such a system. The experience of

${ }_{171}$ L Irish 'The right to development versus a human rights-based approach to development' (2005) 3 International Law Journal of Civil Society 6.

$172 \quad J$ Donnely 'In search of the unicorn: the jurisprudence and politics of the right to development' (1985) 15 California Western International Law Journal 475.

$173 \quad$ Andreassen \& marks (n 56 above) 5 . 
the African Charter on Human and Peoples' Rights also shows that the RTD can indeed be incorporated in binding international treaty if there is the political commitment to do so.

\subsubsection{The question of Feasibility}

The second major objection to the idea of the RTD comes from the fact that development is not feasible in the sense of being fulfilled for all. ${ }^{174}$ Much of the argument for the realization o socioeconomic rights also is similar in that detractors state that the full enjoyment of these rights would not be possible and hence one should abandon attempts to realize such rights. This conception puts the RTD and most socio-economic rights which are central to it outside the scope of human rights. They argue that it would not be feasible to fulfill and guarantee these rights for all, especially in developing countries where there is formidable resource barrier.

This argument against the RTD has been attacked by prominent scholars including Amartya Sen. Sen contends that feasibility should not be a standard by which the cogency of human rights should be measured when the objective itself is to work towards expanding their feasibility and full realization. ${ }^{175}$ The fact that certain rights cannot be realized under current circumstances does not rule out that they are rights. In fact, the promotion and protection of human rights is based on the understanding that there are things that we need to promote and work towards the feasibility of existing and new generations of rights. Moreover, priority setting in some development issues such as poverty reduction through the achievement of the MDGs can also help to focus on addressing urgent development challenges faced by developing countries.

Efforts are also being made under the UN not only in articulating and elaborating the notion of the RTD, but also on its implementation. First under the Global Consultation on the Right to Development and later on under the WGRTD, the UN has been working towards a meaningful realization of the RTD through consultations with IFIs and other actors. ${ }^{176}$

In general, the series of international agreements, custom, and practices have created legal obligations on states and other non-state actors for which they will be accountable. Because of this it is important to state that the RTD satisfies the characteristics of a human right by

\footnotetext{
$174 \quad$ (as above).

$175 \quad$ (as above) 6.

176 Open-Ended Working Group (n 11 above).
} 
identifying specific duty-bearers and specifying their obligations and the corresponding national, ${ }^{177}$ regional ${ }^{178}$ and international monitoring and enforcement mechanisms. It is also important to note that the discourse of international human rights law adopts the notions of implementation and supervision than those of justiciability and enforceability. ${ }^{179}$ This squarely fits with the current trend on implementing the RTD through the WGRTD.

\subsection{IFIs as duty-bearers}

In recent decades the influence of non-state actors in the international economic order has become increasingly important. Trans-National Corporations (MNCs) and IFIs have become important actors not only in economic and financial terms but also in international human rights discourse. Nevertheless, these entities have had marginal considerations to human rights issues and are largely concerned with the market mechanism.

Although states are the primary duty bearers of human rights, non-state actors such as MNCs and IFIs also have their own responsibilities with respect to human rights. In this regard the UN Code of TNCs states that they have the duty to respect human rights and fundamental freedoms in the countries in which they operate. ${ }^{180}$

The UN took initiatives in 1990 in linking human rights with development endeavors while convening the Global Consultation on the Realization of the Right to Development as a Human Right which recommended:

.....United Nations bodies and agencies, including related financial and trade institutions, should respect the International Covenants on Human Rights and other basic conventions in the field of human rights as if they themselves were parties. ${ }^{181}$

The subsequent different Working Groups established to implement the RTD, including the current WGRTD have persistently emphasized the responsibility of the IMF and World Bank in the realization of the RTD. In its second session, the Working Group stated that the concepts

\footnotetext{
177 See the Constitution of the Federal Democratic Republic of Ethiopia (FDRE) Article 43 which expressly guarantees the right of the people of Ethiopia to development.

178 Article 22 ACHPR.

$179 \quad$ Marks (n 23 above) 35.

$180 \quad$ UN Doc. E/1990/94 12 June 1990 para. 14.

$181 \quad$ My emphasis.
} 
contained in the declaration should form ...integral part of the policies and programmes all UN bodies and agencies as well as the Breton Woods Institutions....' ${ }^{182}$

In 1998, when the Committee on ESCR discussed the impact of globalization on the realization of economic, social and cultural rights, it stressed that international financial institutions as well as the governments that they have created and manage them, have strong and continuous responsibility...' ${ }^{\text {'183 }}$ The Committee also made direct reference to the World Bank and IMF to give explicit recognition of socio-economic rights and to devise methods that would consider the impact of their operations on human rights. ${ }^{184}$

IFIs are specialized agencies of the UN that were formally integrated into the UN family. ${ }^{185}$ The relationship agreements contain information sharing between among them. But more importantly, they also include an obligation on behalf of the specialized agency to assist in achieving the objectives of international economic and social co-operation as defined in Article 55 of the UN Charter which also included human rights.

Thus, as a consequence of their status as specialized agencies of the UN, IFIs are under an obligation to contribute to the universal respect for, and observance of human rights, including the RTD. It means that at a minimum the development activities of IFIs should not have adverse effect on the realization of human rights, as laid down in Article 55 of the UN Charter. ${ }^{186}$

As discussed in the above sections, the RTD has been accepted as a fundamental human right through a serious of declarations, resolutions, decisions and conferences of the various human rights organs of the UN. It is argued that these states of facts have given it the status of a fundamental norm of international law through which IFIs are also bound. The deliberations of the WGRTD and its High Level Task Force with a range of actors including, IFIs, donorcommunities and regional financial institutions shows that there is an implicit an acknowledgement of their obligations to implement the RTD.

\footnotetext{
$182 \quad$ UN Doc E/CN.4/1995/11, $5^{\text {th }}$ Sept. 1994, para 37.

$183 \quad$ My emphasis.

184 Committee on ESCR decision on globalization and its impact on the enjoyment of economic, social and cultural rights (1998) UN Doc.E/1999/22 para 5.

185 See Relation agreement of the UN, IMF and World Bank (note 98 above).

186 De Feyter (n 119 above) 270.
} 


\subsection{The implications of the RTD for IFIs}

By defining development as a human right, the RTD reiterates the significance of a development process that aims at social justice and equity and the empowerment of marginalized people. These and other elements of the RTD have important implications for IFIs in the way how a development process should be compatible with human rights

From the perspective of the RTD, the process of development should be participatory with a fair and equitable distribution of benefits that ultimately results in the progressive improvement of the well-being of not just certain economic groups but all people. ${ }^{187}$ According to the RTD, both the process of development and its outcome are integral part of human rights and hence can be claimed as such. ${ }^{188}$ The RTD aims at achieving an outcome whereby people can enjoy their human rights to the fullest extent. These two integral parts of the RTD, i.e. the right to a process of development and the right to certain outcomes of development, correspond to the distinction between obligations of conduct and obligations of result in international human rights law. ${ }^{189}$

The major significance of the RTD is that by bringing all civil and political rights as well as social, economic and cultural rights under one category, it associates development with the principles of equity and justice. ${ }^{190}$

Another important contribution of the right to development is its articulation of a development process that takes into account human rights which is referred as a human rights-based approach to development. A human rights-based approach to development emphasizes on the process of development, its direct links to human rights, on participation and empowerment, non-discrimination, attention to the most vulnerable groups and accountability. ${ }^{191}$ It provides guidance on a development process that takes into account important human rights components and emphasizes that the purpose of development should be the fulfillment of the human rights

\footnotetext{
$187 \quad$ My emphasis.

$188 \quad$ Andreassen \& Marks(n 56 above) 12.

189 See Report of the International Law Commission fifty-first Session (May 3-July 23, 1999) UN Doc.A/54/10, para 145-180.

$190 \quad$ Irish (n171 above) 6.

$191 \quad$ A Sitta The role of the right to development in the human rights framework for development

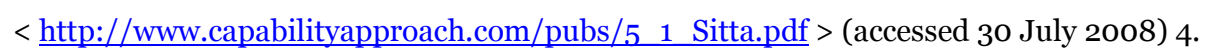


of individuals. It also serves as a tool in the shifting of international development co-operation discourse from a need/charity context to a context of rights/responsibility co-operation. ${ }^{192}$

Different international instruments emphasize on the development dimension of international law and the duty of various specialized agencies of the UN as having a wide range of responsibilities in economic, social, cultural, educational and other fields. ${ }^{193}$

The DRTD also emphasizes the right of states to formulate appropriate national development policies to ensure the continuous improvement of the well-being of their citizens. ${ }^{194}$ By emphasizing the right of states to formulate appropriate policies at their own choice and by recognizing the responsibility of developed countries and IFIs, the RTD lays the foundation for a new international development co-operation that is based on principles of self-determination, participation, accountability and one that respects and protects all human rights.

According to the traditional understanding, development can be achieved by different processes. It can be achieved by an increase in GNP; rapid industrialization or growth in export industries with increased access to global market. At the same time poor people may get poorer and small scale businesses getting weaker without equitable distributions of the benefits of economic growth. These circumstances may be regarded as development in the traditional sense; but cannot be regarded as a right-based process of development from the perspective of the RTD.

Economic growth that marginalizes large proportion of people with high income inequalities does not meet the requirements of the RTD. Economic growth should be associated with improvement in social development, education, health, gender balance and environmental protection. ${ }^{195}$ Moreover, any development process that adversely affects the enjoyment of human rights violates the RTD.

Thus, the RTD emphasizes a development process that empowers the well-being of the entire population including those who are poor to raise their living standards and the capacity to improve their position. It is a process that is centered on the principles of equity and justice. The well-being of people is viewed not just a mere result of economic growth but also the expansion of opportunities and capabilities aimed at expanding their substantive freedoms.

\footnotetext{
$192 \quad$ (as above) 1.

193 See for example Article 57 para 1 UN Charter.

194 Article 2 (3) DRTD

195 A Sengupta 'On the theory and practice of the right to development' (2002) 24 Human Rights Quarterly 848.
} 
The above discussions have important implications for IFIs. The emphasis placed on ensuring equitable distributions of economic benefits, the interdependence of development and human rights and self-determination are significant in serving as a bench mark for these institutions in their operations. By integrating these and other notions of the RTD, the efforts of these institutions in helping developing countries through poverty reduction can be more productive with out at the same time violating human rights.

\subsection{Conclusion}

Since the adoption of the DRTD, the RTD is making an important contribution in changing the fundamental understanding about development itself and the means of achieving it. Although adopted under a declaration which does not have a binding obligation on state parties, its subsequent endorsement by the Vienna Declaration and a series of declarations, decisions resolutions and other international conferences of the $\mathrm{UN}$ human rights bodies has given it the status of a legal right.

Moreover, as composite right incorporating other human rights, its normative foundation is based in international human rights instruments. Thus, IFIs have the duty to assess whether their policies and operations are compatible with the RTD. The notion of the RTD can serve as important benchmark through which comprehensive development and human rights issues can be addressed holistically.

In general, the right to development as en established fundamental principle of international human rights law imposes obligations on IFIs to respect its foundational norms. IFIs should recognize their responsibilities in ensuring that their financed projects and policies adhere to this fundamental principle of international human rights law. Hence, IFI-financed projects and policies that adversely affect the RTD and the enjoyment of human rights in general would amount to violation of international human rights norms for which they will be accountable. 


\section{Chapter Five}

\section{IFIs' accountability mechanisms emanating from the right to development}

\subsection{Introduction}

Human rights accountability of IFIs and non-state actors ${ }^{196}$ in general is one of the most difficult tasks that the international lawyer grapples with. The discussions in the previous chapters have shown that the human rights obligations of IFIs emanates from different sources including their articles of agreement, international human rights law, and public international law. This section looks into the implications of these obligations and mechanism of human rights accountability for IFIs.

It is important to understand at the outset that accountability does not require the rigid attribution of responsibility through the traditional method of court adjudication. Particularly, in the area of international law, we need to acknowledge some of the functional and legal problems faced in articulating such kind of accountability mechanism. While this research does not rule out the possibility for such a redress, it will focus on the mechanisms that can be devised in the institutional apparatus of IFIs and international monitoring and supervising mechanisms.

\subsection{Addressing problems of representation}

The weighted voting system of IFIs remains one of the problems for developing countries to assert their influence in financial and development aspects globally. Although, the influence of IFIs on developing countries has changed fundamentally from what it used to be when these institutions were established, the same rules dictate the decision making process. These impedes their RTD by depriving them a meaningful participation in the decision making process, through

\footnotetext{
196 For a detailed discussion of non state actors obligations with respect to socio economic rights, see Unpublished: DM Chirwa 'Towards binding economic, social and cultural rights obligations of non state actors in international and domestic law: a critical survey of emerging norms' unpublished PHD thesis, University of western Cape, 2005 .
} 
which key policy issues are addressed. In this regard, the General Assembly Resolution on the Right to Development has also reiterated the importance developing countries to have greater representation in decision making powers of IFIs in order to ensure their RTD. ${ }^{197}$

France, the United Kingdom and the United States which are permanent members of the Security Council approximately take 30 percent of the voting power in the World Bank. With respect to the IMF, the US alone holds 17.87 percent; while the collective vote of 47 African countries is a mere 4.38 percent. ${ }^{198}$ This has important consequences in the two institutions. First, it can be a mechanism for reducing or blocking any loans by the Bank or Fund to a country thorough the Security Council for human rights violations. Second, it may lead to abusive consequences by permitting loans to countries with a record of human rights violations because the three countries have decided for politically motivated reasons. ${ }^{199}$ A fair representation system can avoid these kinds of abuses as it would give other states the power to decide on these matters.

This undemocratic and non-participatory nature of the institutions operations has been called into question. If states are to operate on the principle of equality, mutual understanding and consensus, there needs to be a more representative system. Moreover, the impact of IFIs and their involvement in developing countries has become increasingly massive. This demands a greater system of representation than was conceived when these institutions were established more than half a century ago.

Developing countries need to have better representation system that would allow them to influence policy and loan decisions. The underlying foundation of the RTD is also based on dismantling global structural impediments that have historically disfavoured developing countries. Thus, one important aspect of this is that developing countries need to have greater voting powers in the IFIs in matters that usually have pervasive influence in their overall development endeavors.

\footnotetext{
197 General Assembly Resolution on the Right to Development A/RES/6o/157 (23 Feb. 2006) para 20.

198 P Coffey \& RJ Riley Reform of the international institutions: the IMF, the World Bank and the WTO (2006).

$199 \quad$ Ghazi (n 13 above) $85 \& 86$.
} 


\subsection{Human rights conditionalities}

Before delving into the discussion, a distinction should be made between economic conditionality and political conditionality, which includes human rights and issues of democracy and good governance.

Economic conditionalities of IFIs have for the large part involved neo-liberal economic adjustment policies that have adversely affected the enjoyment of socio-economic rights. As showed in the previous sections of this paper, a plethora of evidence has showed that economic conditionalities are not commendable for ensuring the enjoyment of socio-economic rights. Indeed, sustainable economic development that can address the root causes of poverty and empower the marginalized and poor people should be country driven.

The two international covenants and the DRTD make it clear that states have the right to devise appropriate economic policies of their own choice and to utilize their resources without interference. Economic self-determination is thus an important aspect of the RTD, particularly seen from the perspective of developing countries. Therefore, attempts to impose neo-liberal economic policies should be abandoned, not only because they have adverse socio-economic consequences but also because they undermine a fundamental principle of international law.

However, political conditionalities can be a powerful mechanism for ensuring human rights accountability. IFIs can ensure human rights accountability by making sure that their financedprojects and the loans that they grant do not result in the violating human rights. As illustrated in the CCPP and the Lagos Drainage and Sanitation Project, the performance of the projects has resulted in the exacerbation of human rights violations particularly in the areas where the projects were performed. This calls for making explicit reference in loan agreements for respecting international human right standards when implementing IFI-financed projects.

Loan agreements are important means of attaching conditionalities on borrower countries. IFIs, as entities enjoying international legal personality, have the legal capacity under international law to conclude agreements necessary for the achievement of their objectives. ${ }^{200}$ Loan agreements which are concluded between IFIs and borrower states belong to this category. They

200 See Article VII S.2 of IBRD Articles of Agreement Article IX S.2 IMF Articles of Agreement. 
are treaties that are concluded between IFIs and states and hence are governed by international law. ${ }^{201}$

These agreements are binding for both the IFIs and the borrower state that concluded the agreement. The loan agreements are a source of legal obligation for IFIs and failure to implement their obligations would entail international responsibility. ${ }^{202}$ This responsibility arises directly from the breach of the stipulate obligation and when the conduct is attributable to the IFIs.

Loan agreements are indispensable from a human rights perspective by providing an opportunity for the inclusion of human rights protection mechanisms for people that may be potentially affected. Although people whose human rights are violated may not have standing to invoke the loan agreement directly, they can resort to tort law for attributing responsibility in domestic courts. ${ }^{203}$ The domestic courts may take into account the IFIs professional standards to determine the standard of care needed under the circumstances. Some also suggest that a joint responsibility of the IFIs and the borrower state is possible. ${ }^{204}$

\subsection{The World Bank Inspection Panel}

The World Bank Inspection Panel was created in 1993 based on a resolution passed by the Executive Directors of the Bank. ${ }^{205}$ The panel was established to serve as an independent mechanism to ensure accountability for adverse effects of the Bank's operations on the rights or interests of group of individuals. However, the role of NGOs in pressuring the Bank to create such an organ was also significant.

The Panel is composed of three members who have the competence to receive complaints from individuals and groups who allege that they have been harmed by a project financed by the Bank. Subject to the approval of the Board of Executive Directors, the Panel is empowered to

\footnotetext{
201 C Amerasinghe Principles of the institutional law of international organizations (1996) 246; cited in Isa \& De Feyter (n 48 above) 576.

202 Amerasinghe (n 201 above) 240

$203 \quad$ Isa \& De Feyter (n 48 above) 577.

204 For a discussion of joint responsibility by using the concept of complicity for multiple tortfeasers, see A Clapham \& S Jerbi 'Categories of corporate complicity in human rights abuses' (2001) 24 Hastings International and Comparative Law Journal 339.

205 IBRD resolution No. 93/10 \& IDA Resolution No. 93/6 (1993)
} 
investigate problems that are alleged to have arisen because of non-compliance with the Bank's operational policies and procedures.

Because of this, the Panel is limited to reporting on the Bank's compliance with its own policies and hence it is not competent to establish violations of international law or international human rights law. On the other hand, requesters (affected parties) can invoke that their human rights have been affected and nothing prohibits them from alleging such a complaint. This is also consistent with the practice of the panel and the management. As demonstrated in the case studies in chapter two, the management and the Panel responded to human rights claims substantively, and hence impliedly accepting their competence to see allegations of human rights violations.

Critics say that the Board of Executive directors does not fulfill the functions that are usually associated with a judicial body. It does not rule on a specific Bank's practice as a violation of the Bank's operational policies or human rights. The Board does not interpret the legal implications of the policies of the Bank and its findings are based on fact. ${ }^{206}$ Thus, as it stands, the Board and the panel are weak institutions in providing the Bank with effective accountability mechanism on human rights.

Yet, the potential in ensuring human rights accountability under the existing system is enormous. What is needed is a more explicit reference of human rights in the operational policies of the Bank and its articles of agreement. The power to decide on eligibility of complaints for admission and the power to decide on findings should be given to the Panel. The Panel had repeatedly expressed its disappointment by the decision of the Board that overturns the recommendation of the Panel for inspection. The Panel has also been more human rightsfriendly than the management. ${ }^{207}$ If the above issues are addressed well, the Bank can ensure a more effective accountability mechanism under the Inspection Panel.

With respect to the IMF, efforts were made to ensure greater transparency and accountability through the creation of an Independent Evaluation Office. ${ }^{208}$ However, it does not allow individuals or groups affected by its operations to have recourse. The system cannot be considered as a model for human rights accountability and hence there needs to be a fundamental change that would explicitly provide a human rights accountability mechanism.

\footnotetext{
$206 \quad$ Isa \& De Feyter (n 48 above) 580.

$207 \quad$ Ghazi (n 13 above) 220.

$208 \quad$ (As above) 232.
} 


\subsection{Monitoring through international treaty bodies}

Conventionally, states are the only entities that are able to conclude human rights treaties. However, some commentators point out that the World Bank and IMF can be eligible for the ratification of international human rights treaties such as the CESC and the ICCPR. ${ }^{209}$ They have two major reasons for adopting such proposition. First, although most point out that there must be a functional necessity to be able to conclude international treaties, IFIs have implied competence in the area of human rights by their involvement in poverty reduction, the PRSP and MDGs. Second, IFIs have, at the minimum, the obligation to respect ${ }^{210}$ human rights by making sure that the policies they adopt and the conducting of their operations do not infringe up on existing human rights.

This is also consistent with the practice of the Committee on ESCR. The Committee has repeatedly recognized the pervasive violations of human rights that are committed in the name of development by IFIs. It called on these institutions to respect international human rights and to make development and human rights compatible. This is because, at the very least, IFIs have the duty to refrain from violating already existing human rights. As discussed in Chapter three, the CESCR has extraterritorial application through which IFIs are bound to comply with the covenant.

This supervisory mechanism through binding international treaties gives the monitoring body, such as, the committee on ESCR a clear legal mandate on scrutinizing the impact of the policies of IFIs on human rights in a more effective manner. Moreover, information disclosure through the deliberations of the treaty bodies ensures transparency of these institutions and whether they are discharging their obligations with respect to human rights. Accountability and transparency being two key components of the RTD are significant in ensuring its implementation through such international mechanisms.

\footnotetext{
209 See HF Bekker The legal position of international organizations: a functional necessity analysis of their status and immunities (1994) cited in Skogly (n 61 above) 82.

$210 \quad$ My emphasis.
} 


\subsection{The Role of Chartered-based bodies of the UN}

Among the UN Charter based organs, the International Court of Justice (ICJ) and UNCHR, ${ }^{211}$ now renamed the Human Rights Council, ${ }^{212}$ are important organs that could monitor the obligations of IFIs in the observance of human rights.

With respect to the ICJ, although individuals may not be able to exercise jurisdiction, ${ }^{213}$ allegations of human rights violations can be brought by states on behalf of affected individuals. IFIs are international organizations which are governed by international law and hence subject to the jurisdiction of the ICJ. ${ }^{214}$ Scholars ${ }^{215}$ point out that states can have the right to bring an actio popularis, i.e. the right to bring action in matters that may not affect their financial, economic or other material interest. ${ }^{216}$ However, a state has to show at least that there is a remote interest that can be affected, i.e. there should at least be an indirect interest involved under the circumstances. IFIs operation can have adverse consequences socially (migration) and economically (trade, investment, poverty). All these elements can have spillover effects in other countries apart from the affected state. Thus, in these circumstances states can have the right to bring action against IFIs in the ICJ. ${ }^{217}$

The Human Rights Council can also be helpful to establish accountability of IFIs through the 1503 procedure. ${ }^{218}$ This procedure allows the Council to consider allegations of gross and persistent violations of human rights in a particular state. This procedure can be one of the most likely mechanisms to devise human rights accountability mechanism for IFIs. A working group can also be established under the Council to receive communications from individuals and NGOs that allege adverse effects of the operations of IFIs on human rights and engage in discussions with them. This could be significant in that IFIs would take the criticism of high level UN group of experts more seriously and try to avoid similar embarrassment in the future. 


\subsection{The Working Group on the Right to Development}

As discussed in the previous chapters, IFIs are specialized agencies of the UN that were formally integrated into the UN family through relationship agreements. This provides a tremendous opportunity to supervise the policies and activities of IFIs and their impact on human rights.

The UN Charter based system such as the Human Rights Council, the ECOSOC and the General Assembly as well as resolution-based organs that are created by the different organs of the UN such as working groups are important mechanisms of ensuring of human rights accountability of IFIs. The relationship agreements between the UN and IFIs make reference for information sharing and participating in the General Assembly, the ECOSOC and other subsidiary bodies with the former. ${ }^{219}$

The WGRTD is among the first international monitoring bodies that made clear and direct attempts to make formal consultation and institutionalized ties with IFIs. The first Working Group of experts on the RTD while reiterating the need to supervise the activities of IFIs stated:220

The Bretton Woods Institutions (World Bank and IMF) should take account of the right to development in their guiding principles, decision making criteria and programmes... From this point of view, the ties between the World Bank and IMF, on one hand and the United Nations General Assembly and the Economic and Social Council, on the other, should be strengthened. The IMF and the World Bank should be required to submit regular reports to the General Assembly and the Economic and Social Council to keep them informed of the extent to which these institutions are taking account of right to development in their programmes and activities.

Through the WGRTD supported by the High-Level Task Force on the Right to Development, a series of discussions are being conducted between IFIs in order to ensure the RTD in their institutional framework. The emphasis in recognizing the role of these institutions in ensuring the RTD and human rights in general shows their crucial roles and elaborates some of their legal positions in this regard. Both the World Bank and IMF have shown their willingness to cooperate with the WGRTD and the deliberation on the implementation of the RTD.

\footnotetext{
219 See for eg. Article 2(3) \& Article 5 the Relation Agreement between the UN \& IBRD; Article 2 \& 5 Relation Agreement between the UN and IMF.

220 UN Doc E/CN.4/1997/22, 21 January 1997, para 5.
} 
The High-Level Task Force on the Right to Development, under the WGRTD has now become an important body that applies human rights standards to international organizations. It evaluates the human rights impacts of IFIs from the perspective of the RTD. Recently, reflecting the possibility of evaluating a World Bank plan for Africa, the Task Force stated: ${ }^{221}$

Given the preponderant role of the World Bank in the development of Africa and the influence of its thinking and operations on the donor community at large, its partnership should be critically scrutinized. Accordingly, the Bank should therefore be invited by the Working Group to allow the African Action Plan and its partnerships with governments of Sub-Saharan Africa to be evaluated against the criteria of the right to development.

In brief, the WGRTD provides a tremendous opportunity to integrate the notion of the RTD in a comprehensive and multi disciplinary manner. It serves as a forum where by IFIs, donor communities, NGOs, governments and other stakeholders can deliberate on mechanisms of implementing the RTD in a wider context.

\subsection{Conclusion}

The increasing importance of non-stat actors, notably IFIs, in the international arena calls for mechanism that could make them accountable for the impact of their general polices and financed-projects on human rights. Much of the scholarly work on human rights has concentrated the discussion on the general impacts of IFIs activities on human rights. While this is important to show the magnitude and the pervasiveness of the issue, it is also crucial to scrutinize some of the possible mechanisms that would help in increasing the accountability of these institutions.

A closer look at some of the institutional framework of IFIs, UN Charter and resolution-based bodies shows that accountability mechanisms can be devised for these institutions. Particularly, the WGRTD provides a unique opportunity through which the policies of IFIs and their activities can be scrutinized vis-à-vis the RTD.

Nevertheless, some of the issues such as those referring to the prohibition of political interference in member countries still remain impediments for effective human rights accountability mechanism. It should also be noted that all of these efforts can be bolstered when

221 Report of the High-Level Task Force on the Implementation of the Right to Development, $3^{\text {rd }}$ session (2007)UN Doc.A/HRC/4/WG.2/TF/2, para 87. 
there is the political commitment and the willingness of all stakeholders in ensuring accountability, transparency and respect for the observance of human rights.

In the following section, the paper highlights the concluding remarks and recommendations that show areas of intervention for policy makers concerned in the area of human rights and development. 


\section{Chapter Six}

\section{Conclusion and recommendation}

\subsection{Conclusion}

Although generalizations are difficult to make about its effects, a plethora of evidence shows that globalization intensifies inequalities, both in its national and international dimensions. It further worsens the precarious position of the poor and vulnerable people, particularly in developing countries. ${ }^{222}$ The World Bank and IMF have become major agents of the globalization process that vigorously promote economic policies and processes associated with globalization such as privatization, liberalization, cuts in social service expenditures and the creation of legal regimes promoting foreign investment.

IFIs have defended their policies by stating that their economic activities will advance human welfare and that economic benefits will trickle down to the larger population. Nevertheless, equity, social justice and human rights are not the explicit concern of these institutions.

The insistence of IFIs that they will not interfere in the political affairs of member states and their persistent position that only economic considerations shall be relevant in their policy decisions seriously undermines the integration of human rights in the development process. The few attempts made by IFIs to integrate human rights in their institutional framework have been ad hoc and ambiguous. The effect of this has been that these forces of globalization have led to the deterioration of the socio-economic rights of individuals by creating formidable obstacles for developing countries to adopt policies which are counterproductive to the promotion of human rights. IFI-financed projects have also led to adverse consequences by violating human rights of individuals.

The RTD fosters efforts to be made in examining human rights issues in a comprehensive and much wider context than has traditionally been the case, to encourage interdisciplinary analysis

\footnotetext{
222 Commission on Human Rights Resolution 2002/69 on the Right to Development, inter alia stated '... while globalization offers both opportunities and challenges, the process of globalization remains deficient in achieving the objectives of integrating all countries in a globalised world and stresses the need for policies and measures at the national and global levels to respond to challenges and opportunities of globalization if this process is to be made fully inclusive and equitable. See also N Bridsall 'Life is unfair: Inequality in the World' (1998) 111 Foreign policy 76.
} 
of human rights problems and to show the inadequacy of the existing human rights framework to address structural problems.223 The RTD provides a unique opportunity to promote an international economic order that is based on equity, social justice, and one that integrates human rights in different dimensions. It has been argued in this research that the RTD, though conceived under a declaration has evolved into a legal right through a series of declarations and resolutions. The fact that it is a composite right that incorporates all other rights also makes its normative foundation implicit in the different international human rights instruments.

By emphasizing the indivisibility and interdependence of human rights, the RTD reiterates that any development process must acknowledge that the promotion and protection of human rights is part of that process. More importantly, development is defined as a human right that has the objective of fulfilling the continuing improvement of the well-being of individuals by expanding their capabilities and their freedom.

In recent decades, the World Bank and IMF have become the most important organs that are increasingly involved in poverty reduction efforts and achieving the MDGs by helping developing countries. Nevertheless, the lack of explicit and clear approach towards human rights has become a major impediment in making meaningful impact to the lives of people in the developing world. Because of this, policies and projects undertaken in the name of development have adversely affected the enjoyment of human rights.

Structural violations of human rights occur through the imposition of neo-liberal economic policies by IFIs that force developing countries to undertake inter alia privatization and cuts in social service expenditures. These policies have the effects of impeding and deteriorating the socio-economic rights of individuals by diverting resources and thereby further marginalizing the poor who are in desperate need. More direct violations of human rights occur through projects undertaken in the name of development that adversely affect the lives of people by disregarding international human rights standards. The CCPP and the Lagos Drainage and Sanitation Projects have illustrated some of the critical issues that are raised with respect to IFIfinanced projects and the protections of human rights.

Although the recent initiatives of these institutions towards human rights, particularly those referring to indigenous peoples and the recognition of the implications of the social dimensions of development are commendable, there are still formidable institutional barriers that need to be worked out.

$223 \quad$ Marks (n 23 above). 


\subsection{Recommendations}

The research highlighted the problem areas with respect to the difficulties involved in making human rights and development compatible. These discussions call for policy interventions by different stakeholders involved in the issue of human rights and development. The following are recommendations that call for areas of intervention by all stakeholders to make the promotion and protection of human rights effective in the development process.

First, the adoption of a legally binding treaty on the RTD with more normative precision of its contents and clear obligations on duty-bearers is indispensable for a meaningful realization of the right. Although the author maintains that the RTD is a legal right, one has to concede the fact that one of the major problems in its implementation has been the declaratory nature of the DRTD. Thus, a binding treaty with a competent supervisory body that can monitor the implementation of the RTD is crucial for its effective realization. In this regard if there is the political commitment, the experience of the African Charter has shown that the RTD can be a legally enforceable right through treaty bodies.

In view of the ambivalent nature of the approach of IFIs to human rights, a clear approach that expressly recognizes the RTD as a human right and their responsibility in the promotion and protection of human rights in general is essential. The current constitutional documents, operational policies and the general policies of IFIs do not make explicit reference to human rights. More explicit reference would be important in guiding these institutions on their responsibilities and their roles in the promotion and protection of human rights in clearer terms.

Regarding the representation system, IFIs should undertake institutional reform that could accommodate greater participation of developing countries which can help them influence policy decisions. IFIs were established in the aftermath of World War II and hence their primary focus was to reconstruct the war torn European economies. Thus, at the beginning most of the loan recipient countries were European countries while most of the developing countries were under colonial rule. Currently, all the lending of the IFIs goes to developing countries and countries in transitional economies. Nevertheless, the culture and the modus operandi of the IFIs largely remains what it used to be more than half a century. This calls for a major change in the institutional structure of the two institutions to meet the demands of the $21^{\text {st }}$ Century. Among these, the current weighed voting system of these institutions makes most developing 
countries voiceless in key and important policy issues. Thus, a more representative system for developing countries in the decision making bodies of IFIs is indispensable to ensure that their interests are protected.

With respect to economic self-determination, it is crucial that developing countries be allowed to devise economic policies that are relevant to their context and circumstances. The continuing trend of IFIs to dictate neo-liberal economic policies is incompatible with the purpose of empowering the poor and addressing the root causes of poverty. As an established principle of international law, the right to self-determination also allows developing countries to design appropriate socio-economic policies relevant to their needs. Drawing the lessons from the failed policies of the SAPs and the adverse effects of imposing other western model neo-liberal approaches, IFIs should refrain from imposing such policies. If at all, the role of IFIs in economic matters should be advisory. However, coercive means of imposing economic conditionalities undermines a fundamental principle of international law and hence should be abandoned.

Lastly, strengthening the existing human rights accountability mechanisms for IFIs is crucial for the effective protection and promotion of human rights. Both the internal self-regulatory mechanisms of the IFIs and external accountability mechanisms have to be improved with a clear mandate to decide on cases of human rights violations that occur because of the policies and operations of IFIs. Particularly, the WGRTD has a crucial role to play in addressing the issue of the RTD and human rights in general vis-à-vis the development process. This body should be given the legal mandate to supervise the operations of IFIs through a binding international treaty. By doing so, comprehensive and wide ranging problems related with the development process and human rights can be addressed in more effective manner. 


\section{Bibliography}

\section{Books}

Aguda, TA (1989) Human rights and the right to development in Africa: Nigerian Institute of International Affairs.

Alston, P (ed) (2005) Non-state actors and human rights: Oxford university press.

Alston, P \& Robinson, M (eds) (2005) Human rights and development: towards mutual reinforcement: Oxford University Press.

Andreassen, BA \& Marks, S (eds) (2006) Development as a human right: legal, political and economic dimensions: Harvard University Press.

Coffey, P \& Riley, RJ (2006) Reform of international institutions: the IMF, World Bank and the WTO: Edward Elgar Publishing.

Chowdhury, SR; Denters, E MG \& De Waart, P JIM (eds) (1992) The right to development in international law: Martinus Nijhoff Publishers.

Dugard, J (2005) International law: a South African Perspective: Juta Co. Ltd.

Darrow, M (2003) Between light and shadow: the World Bank, the International Monetary Fund and international human rights law: Hart Publishing.

De Feyter, K \& Isa, FG (eds) (2005) Privatization and human rights in the age of globalization: Intersentia publishers.

De Feyter, K (2001) World development law: Sharing responsibility for development: Intersentia Publishers.

Ghazi, B (2005)The IMF, the World Bank Group and the Question of Human Rights: Transnational publishers.

Isabella, B (2006) The right to development and International economic law: Oxford Unversity Press.

Isa, FG \& De Feyter, K (eds) (2006) International Protection of human rights: achievements and challenges: University of Deusto. 
Marks, SP (2004) The human right to development: between rhetoric and reality: Cambridge university press.

Marks, SP (2003) Obstacles to the right to development: Harvard University Press.

Nanda, VP; Shepherd, GW JR \& Arnolds, EM (eds) (1993) World debt and the human condition: structural adjustment and the right to development: Greenwood Press.

Paloni, A \& Zanardi, M (eds) (2006) The IMF, World Bank and policy reform: Routledge.

Salmon, ME; Tostensen, A \& Vandenhole, W (eds) (2007) Casting the net wider: human rights, development, and new duty bearers: Intersentia Publishers.

Schrijver, N \& Weiss, F (eds) (2004) International law and sustainable development: Martinus Nijhoff Publishers.

Sepulveda, M; Van Banning, T; Chamoun, C \& Van Genugten, WJM (eds) (2004) Human rights reference hand book: University for Peace.

Skogly, SI (2001) Human Rights obligations of the World Bank and the International monetary Fund: Cavendish Publishing Ltd.

Viljoen, F (2007) International human rights law in Africa : Oxford University Press.

\section{Journal Articles}

Ambrose, S ‘Multilateral debt: the unbearable burden' (2001) 6 Foreign Policy in Focus 37.

Auguirre, D 'Restricted development: the entrenchment of structural adjustment and human rights law' (2006) 18 Sri Lanka Journal of International Law 1.

Barsh, RL 'The right to development as a human right: results of the global consultation' 13 Human Rights Quarterly 322.

Bradlow, DD 'The World Bank, IMF and human rights' (1996) 6 Transnational Law and Contemporary Problems 59.

Bradlow, DD \& Grossman, C 'Limited mandated and intertwined problems: a new challenge for the World Bank and the IMF' (1995) 17 Human Rights Quarterly 416. 
Bridsall, N 'Life is unfair: Inequality in the World’ (1998) 111 Foreign policy 76.

Bunn, ID 'The right to development: implications for international economic law' (1999-2000) 15 American University International Law Review 1431.

Clapham, A \& Jerbi, S 'Categories of corporate complicity in human rights abuses' (2001) 24 Hastings International and Comparative Law Journal 339.

Delescluse, A 'Chad-Cameroon: a model pipeline?' (2004) 5 Georgetown Journal of International Affairs 43.

Donnely, $\mathrm{J}$ 'In search of the unicorn: the jurisprudence and politics of the right to development' (1985) 15 California Western International Law Journal 475.

Eide, A 'Human rights requirement to social and economic development' (1996) 21 Food Policy 23 .

Howard, R ' The full belly thesis: should economic rights take priority in over civil and political rights? Evidence from Sub Saharan Africa’ 5 Human Rights Quarterly 467 (1983).

Irish, L 'The right to development versus a human rights-based approach to development' (2005) 3 International Law Journal of Civil Society 6.

Marks, S 'Making space for new human rights: the case of the right to development' (1998) 1 Harvard Human Rights Year Book 3.

Mansel, W \& J Scott , J 'Why bother about a right to development? (1994) 21 Journal of Law and Society 171.

Mazur, RE 'Realization or deprivation of the right to development under globalization? Debt, structural adjustment and poverty reduction programs' (2004) Georgetown Journal 68.

Oloka-Onyango, $\mathrm{J}$ 'Beyong the rhetoric: reinvigorating the struggle for economic and social rights in Africa' 26 California Western International Law Journal 1. 
Owens , JC 'Government failure in Sub-Saharan Africa: the international community's options' (2003) 43 Va. Journal of International Law 197.

Paul , J CN 'The Human right to development: its meaning and importance' (1992) Third World legal Studies 17.

Perry, RW 'Rethinking the right to development: after the critique of development, after the critique of rights' (1996) 18 Law and Policy 228.

Rich, RY 'The right to development as an emerging human right' 23 Virginia Journal of International Law 322 (1983).

Sengupta, A 'On the theory and practice of the right to development' (2002) 24 Human Rights Quarterly 837.

Sheehy , O 'The right to development and the proliferation of rights in international law' (2002) 5 Trinity Law Review 253.

Shihata, I 'Democracy and development' (1996) 46 International Law Quarterly 639.

Suzuki , E 'The fallacy of globalization and the protection of national economies' (2001) Yale Journal of International Law 319.

Uriz, GH 'To lend or not to lend: oil, human rights and the World Bank's internal contradictions' (2001) 14 Harvard Human Rights Journal 198.

Uriz , $\mathrm{GH}^{`}$ The application of the World Bank standards to the oil industry: can the World Bank Group promote corporate responsibility?' (2002) 28 Brooks Human Rights Journal 77.

\section{Thesis}

Un published: DM Chirwa 'Towards binding economic, social and cultural rights obligations of non state actors in international and domestic law: a critical survey of emerging norms' unpublished PHD thesis, University of western Cape, 2005. 


\section{UN official reports}

Report of the Secretary-General on the International Dimensions of the Right to Development as a Human Right, UN ESCOR $35^{\text {th }}$ Sess, paras. 152-159, U.N. Doc. E/CN.4/1334 (1979).

Report of the Working Group of Governmental Experts on the Right to Development, U.N. ESCOR 45 ${ }^{\text {th }}$ Sess. Para. 25 U.N. Doc. E/CN.4/1989/10 (1989).

Report of the Working Group on the Right to Development second session, UN Doc. E/1990/94 12 June 1990.

Report of the Working Group on the Right to Development, E/CN/4.RES/1998/72.

Report of the Working Group on Structural Adjustment Programmes and Economic, Social and Cultural Rights UN Doc:E/CN.4/1995/51 (11 march 1999) para11.

Fourth Report of Independent Expert on the RTD, Mr Arjun Sengupta, UNCHR E/CN.4/2002/WG.18/2 (2001) para $51 \& 52$.

Inter-governmental Working Group of Experts on the Right to Development second session U.N.Doc.E/CN.4/1998/29; See also General Assembly Resolutions on the RTD, A/RES/54/175 (15 Feb. 2000) \& A/RES/6o/157 (23 Feb. 2006).

Report of the High-Level Task Force on the Implementation of the Right to Development, Third session (2007), UN Doc.A/HRC/4/WG.2/TF/2.

Report of the International Law Commission fifty-first Session (May 3-July 23, 1999) UN Doc.A/54/10, para 145-180.

B Mundho Effects of structural adjustment policies and foreign debt on the full enjoyment of human rights, particularly economic, social and cultural rights UN Doc. E/CN.4.2003/10 (23 Oct. 2002). 
F Cheru Effects of structural adjustment policies on the on the full enjoyment of human rights, UN Doc. E/CN .4 /1999/50 (24 February 1999) 16.

F Cheru The Highly Indebted Poor Countries (HIPC) Initiative: a human rights assessment of Poverty Reduction Strategy Papers (PRSPs) (2001) UN Doc. E/CN.4/2001/56.

Paul JIM Waart Global consultation on the Realization of the Right to Development as a Human Right ER/RD/1990/Conf.15 (12 Jan. 1990).

UNCTAD the Least Developed Countries Report, 'Escalating the poverty trap' (2002) IV-IX.

UN Doc E/CN.4/1995/11, $5^{\text {th }}$ Sept. 1994, para 37.

UN Doc. A/RES/3281 (XXIX) (1975).

\section{Legal instruments}

African Charter on Human and Peoples' Rights adopted June 27 1981, entry into force 21 October 1986.

Agreement between the United Nations and the International Bank for Reconstruction and Development, 16 UNTS 346 (1948).

Agreement between the United Nations and the International Monetary Fund, 16 UNTS 328 (1948).

Commission on Human Rights Resolution 2002/69 on the Right to Development.

Commission on Human Rights, Resolution 2001/27 UN Doc: E/CN.4/RES/2001/27.

Declaration on the Right to Development adopted by General Assembly Resolution 41/128 (4 Dec.1986).

ECOSOC Resolution 1503 (XLVIII) of 27 May 1970 
ECOSOC Res.E/RES/5(I) (16 Feb. 1946).

ECOSOC Resolution 5/1 ( 2007).

General Assembly Resolution on the Right to Development A/RES/60/157 (23 Feb. 2006).

General Assembly Resolution 34/46 (1979).

General Assembly Res UN Doc.A/RES/60/251(2006).

International Covenant on Civil and political Rights, adopted 16 December 19666, entry into force 23 March 1976.

International Covenant on Economic, Social and Cultural Rights, adopted 16 December 1966, entry into force 3 January 1976.

International Bank of Reconstruction and Development, Resolution No. 93/10.

International Development Association, Resolution No. 93/6 (1993).

The Constitution of the Federal Democratic Republic of Ethiopia, Proclamation No. 1/1995.

UN Doc. E/CN.4/SR1389, 1392-98 (1977), Resolution 5 (XXXIII).

UN Commission on Human rights Resolution E/CN.4/RES/2001/27.

United Nations Declaration on the Establishment of a New International Economic Order GA Res. 3201(S-VI) U.N. GAOR $6^{\text {th }}$ Special Sess. Agenda Item 6, 2229 $9^{\text {th }}$ plen. Mgt. at U.N. Doc. A/RES/3201(S-VI) (1974).

United Nations Millennium Declaration A/RES/55/2 (18 Sep. 2000).

United Nations Charter, adopted in 26 June 1945.

Universal Declaration on Human Rights, adopted 10 Dec. 1948. 
United Nations Code of Trans-National Companies, UN Doc. E/1990/94 12 June 1990

UN Commission on Human Rights Resolution 1989/45 (6 March 1989), 'The Realization of the Right to Development' Global Consultation on the Right to Development as a Human Right HR/PUB/91/2 United Nations, New York, (1991).

Vienna Declaration and Programme of Action A/CONF.157/23 (12 Jul. 1993).

\section{General Comments, Decisions and concluding observations}

Committee on ESCR General Comment No. 2 para 6

General Comment No. 7 para 18.

General Comment No. 14 para 64.

General Comment No. 12 para 41.

General comment No. 15 para 60.

Concluding Observations, Brazil 23/05/2003 E/C.12/1/Add.87.

Concluding Observations: Norway, UN Doc.E/C.12/1/Add.109 (2005)

para 35.

Concluding Observations: Denmark, UN Doc.E/C.12/1/Add.102 (2004)

para 5 .

decision on Globalization and its Impact on the Enjoyment of Economic, Social and Cultural Rights (1998) UN Doc.E/1999/22 para 5.

UN Commission on Human Rights decisions, E/CN.4/DEC/1997/103; E/CN.4/DEC/1998/102. 


\section{Working papers and reports}

A Sen Development thinking at the beginning of the 21st Century (1997) : London School of Economics.

I Jonathan et al 'Civil liberties, democracy, and the performance of government project' World Bank Economic, Review Vol. 11 (May 1997) 219-242.

I Jonathan et al 'Does participation improve performance? establishing causality with subjective data' World Bank Review Vol. 9 (May 1995).

Inspection Panel, Investigation report on Chad-Cameroon Petroleum and Pipeline Project (17 July 2002 ) para 12.

The African Charter on Human and peoples' Rights $3^{\text {rd }} \& 4^{\text {th }}$ Periodic Report of Algeria (2006).

The African Charter on Human and peoples' Rights $8^{\text {th }}$, $9^{\text {th }}$ and $10^{\text {th }}$ Periodic reports of the Democratic Republic of Congo (2007) para 208.

World Bank, Operational Policies: Poverty reduction, OP 1.00 (2004) Washington DC, World Bank.

World Bank Operational Directive 4.20 on Indigenous Peoples (1991).

\section{Web sites}

$<$ http://www.imf.org $>$

$<\underline{\text { http://www.worldbank.org }>}$

$<$ http://www.un.org $>$

<http://www.hrw.org $>$

$<\underline{\text { http://www.achpr.org }>}$ 


\section{Internet Sources}

A Sitta The role of the right to development in the human rights framework for development $<$ http://www.capabilityapproach.com/pubs/5 1 Sitta.pdf $>$ (accessed 30 July 2008) 4.

J Wolfensohn A proposal for a comprehensive development framework (1999) $<$ http://www.worldbank.org.cdf $>$ (accessed on 16 Sep. 2008).

Participation and Civil Engagement Group (PCEG): Participation in poverty reduction strategy papers: a retrospective study <http://wwwworldbank.org/participation $>$ (accessed 3 Oct. 2008).

Press Release No: 2009/o73/AFR http://go.worldbank.org/LNOXOH2W50 (accessed 7 Oct. 2008).

<http://go.worldbank.org/IHDUWCAI20 > (accessed 8 Sep. 2008).

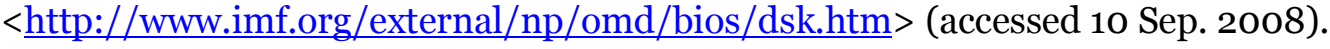

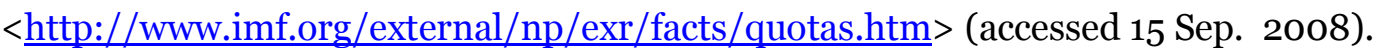

<http://wwwworldbank.org/participation $>$ (accessed 3 Oct. 2008).

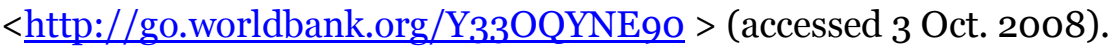

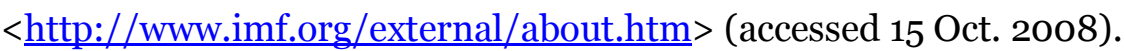

<http://www2.ohchr.org/english/bodies/chr/complaints.htm $>$ (accessed 12 Oct. 2008). 


\section{Chapters in books}

A Sengupta 'Implementing the right to development' in $\mathrm{N}$ Schrijver \& $\mathrm{F}$ Weiss (eds) 'International law and sustainable development: principles and practices' (2004) 15.

\section{Cases}

Belgium v Spain (1970( ICJ reports.

Ethiopia \& Liberia $v$ South Africa Preliminary objections Judgment (21 Dec.1962) (1962) ICJ Reports 424 .

France v Germany (1923) IPCJ Series A, No 1.

Portugal v Australia (1995) ICJ reports 102. See also United States v Iran (1980) 43.

Reparation for Injuries case (1949) ICJ Reports 174.

Social and Economic Rights Action centre (SERAC) and Another v Nigeria (2001) AHRLR 60 (ACHPR 2001). 